\title{
Site ${\mathrm{C} 0015^{1}}^{-12}$
}

\author{
Expedition 331 Scientists $^{2}$
}

\section{Chapter contents}

Background and objectives.......... 1

Operations................... 2

Lithostratigraphy.............. 2

Biostratigraphy ............... 3

Petrology..................4

Geochemistry ................ 4

Microbiology ............... 5

Physical properties .............6

References.................6

Figures................ 8

Tables...................... 31

'Expedition 331 Scientists, 2011. Site C0015. In Takai, K., Mottl, M.J., Nielsen, S.H., and the Expedition 331 Scientists, Proc. IODP, 331: Tokyo (Integrated Ocean Drilling Program Management International, Inc.).

doi:10.2204/iodp.proc.331.105.2011

'Expedition 331 Scientists' addresses.

\section{Background and objectives}

Integrated Ocean Drilling Program (IODP) Site C0015 is located near the crest of the main hill that lies to the west, $\sim 600 \mathrm{~m}$ northwest of the main hydrothermal mound chains of the Iheya North field (see Fig. F3 in Expedition 331 Scientists, 2011a). The preexpedition survey of the area surrounding Site C0015, using a remotely operated vehicle (ROV), found many colonies of deep-sea vent mussels, all dead, as well as widespread pavements of carbonate and/or sulfate crusts. We hypothesize that the crest of the hill west of the Iheya North vent sites was an enormous methane seepage field in the past.

A heat flow survey of the entire hydrothermal field (see Fig. F1 in Expedition 331 Scientists, 2011c) shows that Site C0015 has relatively low heat flow and a surficial temperature gradient of $\sim 1^{\circ} \mathrm{C} / \mathrm{m}$, much lower than at Sites C0013 and C0014. A significant feature of Site C0015 revealed in the seismic reflection survey is the presence of a large-scale sequence of negatively polarized reflections, the eastern end of which appears to converge into the seafloor near the vent sites (see Fig. F6 in Expedition 331 Scientists, 2011a). The three-dimensional extension of the negative polarity sequences seems to extend beneath the thick basin-filling sediments that are widespread in the northern and western parts of Iheya North Knoll (Fig. F1). These sequences are thought to consist of highly porous layers of pumiceous volcanic sediment that could serve as a reservoir and/or migration paths for subseafloor hydrothermal fluids. Seismic reflection data suggest further that the negative polarity sequences reach a maximum thickness of $\sim 100 \mathrm{~m}$ just beneath the hill west of the hydrothermal vent sites (see Fig. F6 in Expedition 331 Scientists, 2011a) and could represent the final storage volume for hydrothermal fluid before it ascends to the east along the westward-dipping structure and exits the seafloor at the high-temperature vent sites (see Fig. F6 in Expedition 331 Scientists, 2011a).

The scientific objective for Site C0015 is to test whether the negative polarity reflectors imaged seismically represent a hydrothermal reservoir and/or fluid migration pathway that might deliver fluids to the vents and associated microbial communities. As much as $400 \mathrm{~m}$ of penetration would be required to penetrate the deepest of these reflectors at Site C0015, but we had time to take only two hydraulic piston coring system (HPCS) cores, to 9.4 meters below seafloor (mbsf), before we had to depart for Okinawa, 
Japan, for a crew change midway through the expedition.

\section{Operations}

\section{Arrival at Site C0015}

The D/V Chikyu moved to Site C0015 on the morning of 18 September 2010, with the bottom-hole assembly (BHA) hanging at $500 \mathrm{~m}$ water depth. The last $500 \mathrm{~m}$ was covered in dynamic positioning mode with the BHA lowered to $911 \mathrm{~m}$ water depth while the ROV was deployed for a seafloor survey (Table T1; Fig. F2).

\section{Hole C0015A}

Hole C0015A was drilled without coring on 18 September 2010 to 6 mbsf to check the hardness of the formation. The seabed was found to be soft enough to penetrate with the HPCS for at least the mudline core.

\section{Hole C0015B}

The first cored hole (C0015B, on 18 September 2010) was $1 \mathrm{~m}$ south of Hole C0015A. The bit tagged the seafloor at $914.5 \mathrm{~m}$ water depth and pulled up to $3 \mathrm{~m}$ above seafloor. The hole was shot with the HPCS from 0 to $6.5 \mathrm{mbsf}$, after which the bit was pulled back up.

\section{Hole C0015C}

The second core was taken $4 \mathrm{~m}$ northeast of Hole C0015A on 18 September 2010. The seafloor was tagged at $914 \mathrm{~m}$ water depth, and the hole was drilled ahead to $6.5 \mathrm{mbsf}$ before the HPCS was shot. The coring shoe penetrated only $2.9 \mathrm{~m}$, to a total depth of 9.4 mbsf. Discoloration of the core liner suggested it was affected by heat.

\section{Lithostratigraphy}

Despite the relatively short interval cored (0-9.5 mbsf), a broad diversity of sediment types was drilled at Site C0015, with coarse pumiceous gravel and grit, siliciclastic sand, hemipelagic mud, bioclastic gravel, and foraminiferal sediment all recovered. In order to be consistent with nomenclature applied to other sites drilled during this expedition, these interlayered sediments are grouped as a single lithostratigraphic unit (Unit I), but 14 subunits (Ia-In) are defined based on sediment type (Fig. F3; Table T2).

\section{Sediment types cored at Site C0015}

Table T2 describes the lithologic subunits cored at Site C0015. This information is presented as a sedimentary log in Figure F3. Subunits are described below and grouped by lithotype.

\section{Coarse pumiceous gravel and grit Woody pumice gravel}

Woody pumice exhibits tubular structure, with tubes $\sim 2 \mathrm{~mm}$ in cross section. These tubes give the pumice unique sedimentological properties, as they rapidly imbibe water and reduce the buoyancy of clasts, causing them to sink near the locale of effusion (Kato, 1987). Woody pumice is a local term for the tube pumice found widely in the Okinawa Trough region, and the term has been used in the region for some time. Woody pumice breccia near the seafloor comprises angular clasts of woody pumice that are generally black at this site (lithologic Subunit Ia). Near the top of Hole C0015B, a $2.8 \mathrm{~m}$ thick layer of pumice breccia displays inverse to normal grading (Subunit Ib). The base and top of the deposit comprise a coarse sand matrix of pumice fragments with a minor but significant mud fraction that was observed to make the unit more cohesive. Without this matrix, pumice gravels are effectively unconsolidated submarine talus.

Woody pumice gravel also occurs deeper in the sequence as Subunits If and Ik. In these intervals, pumice beds grade upward into matrix-supported bioclastic gravel and siliceous sand, respectively (Fig. F3). Pumice breccia with a poorly sorted brown mudsand matrix and a significant (20\%-30\%) bioclast component was cored in Hole C0015B (Subunit Ie). This bed passes up into hemipelagic mud without any sharp depositional contact (Subunit Id). Coarsegrained sand was cored in Hole C0015C, at the base of which is a pumice layer (Subunit Ii). In this instance, the unconsolidated nature of the coarsegrained sediment, combined with disruption during core recovery, prevented observation of the depositional contact.

\section{Pumice gravel and grit}

Other pumice breccias in which the significant clastic component is not woody pumice were encountered in both holes (Subunits Ih, Ii, Im, and In; Fig. F3). In Subunits Ih and Ii, clasts are vesicular and have a frothy texture, but not to the extent of tube pumices. For Subunits Im and In in Hole C0015C, disruption due to drilling is high, and lack of a supporting matrix (which may have been flushed from 
the core) makes it difficult to discern sedimentary contacts.

\section{Siliciclastic sand}

Two siliciclastic sand intervals are present in Hole C0015C (Subunits Ij and Il; Fig. F3). Although the core is highly disturbed by drilling, the sands are texturally mature, comprising well-rounded, spherical, and well-sorted medium-grained quartz.

\section{Hemipelagic mud}

Hemipelagic mud is a major matrix component of most of the coarser sediments at Site C0015 and forms a distinct subunit (Subunit Ig) between 5.5 and 5.89 mbsf in Hole C0015B (Fig. F3). This interval displays visible laminae of silt and fine sand, indicating a possible mixed hemipelagic-siliciclastic origin. Foraminifers are abundant in these muds and are also common where mud forms a component of the matrix in volcanic breccias, although in this instance the foraminifers have holes and other evidence of damage, suggesting that they have been reworked.

\section{Bioclastic gravel}

The interval from 3.2 to 5.07 mbsf in Hole C0015B (Subunit Ie; Fig. F3) comprises bioclastic gravel that contains $\sim 20 \% 1-2 \mathrm{~cm}$ fragments of branching coral and mollusk shells supported in a matrix of dark olive-green plastic reduced silty hemipelagic mud. The silt fraction in the interval consists of biogenic material (foraminifers, fish teeth, and shell and coral fragments), with minor pumice and trace fine-grained framboidal pyrite. Rare subrounded pumice fragments, ranging in size up to $4 \mathrm{~cm}$, are also present in the subunit. Subunit Ie has gradational contacts into both the overlying foraminiferal sand and underlying woody pumice gravel subunits.

\section{Foraminiferal sediment}

Subunit Ic (2.95-3.05 mbsf) and Subunit Id (3.05-3.2 mbsf) are baby poo yellow foraminifer-rich sedimentary units separated by a sharp depositional contact (Fig. F3). The upper subunit is well sorted, well rounded, and medium grained and contains abundant foraminifers, minor scaphopods, fish teeth, and other biogenic material. Siliciclastic components comprise $\sim 10 \%$ of the interval. Subunit Id is finer grained and less well sorted and grades into the underlying bioclastic gravel subunit.

\section{Discussion and implications}

The tendency for woody pumice to be deposited close to its point of eruption/effusion in a subaqueous volcanic setting (Kato, 1987) must be considered in any interpretation of the pumice horizons encountered at Site C0015. The inverse to normal grading of the thickest pumice breccia (Subunit Ib) in Hole C0015B (0.15-2.95 mbsf) is significant, as it is diagnostic for a proximal debris flow or mass wastage deposit. Inverse to normal grading is observed in breccia associated with mass wasting (Walker, 1992). The poorly sorted mud matrix and the large variety of texturally immature clasts in the bioclast-rich breccia (3.2-5.07 mbsf; Hole C0015B, Subunit Ie) is also consistent with a debris flow or mass waste; in this instance a greater variety of clast types has been resedimented. Thus, volcanic and other clast types at this locality have been redeposited from their initial point of deposition, albeit in close vicinity to their source.

Sharp sedimentary contacts with overlying pelagic mud are absent for most breccia horizons, probably because of the high porosity of the talus or scree beneath. Under these conditions, sediment of clay-size fraction infiltrates the top of the underlying formation.

In many oceanic volcanoes, debris flows triggered by flank collapse outnumber those triggered by caldera collapse or other volcanic activity (Schmincke, 2004). In such a depositional regime, lithology varies over short distances and thick units do not necessarily have a wide lateral extent. Stratigraphic correlation in an actively mass wasting environment, particularly the flank of a volcano, is thus complicated, although bounding surfaces will form during the long hiatuses between depositional events, when hemipelagic sedimentation dominates. These surfaces, however, may still be disrupted by further debris flows. Figure F4 illustrates an analogous setting to Iheya North Knoll, illustrating the difficulty inherent in understanding subsurface fluid flow at the site. Laterally extensive hemipelagic mud would be expected to act as a barrier or baffle to fluid flow. Coarser, more permeable and porous layers will often possess better hydraulic conductivity, although matrix-supported intervals would be significantly less permeable.

\section{Biostratigraphy}

Paleontological (PAL) samples from Site C0015 in sediments and core catcher material generally consist of pumice clasts and fragments (Table T3). Sediment samples from $~ 8.9$ mbsf in Hole C0015C (0.1 g provided by the microbiology group), and from $\sim 9.5$ mbsf in the same core (the bottom of the core) also possess iron oxides (Fig. F5; cf. Fig. F6). The presence of iron oxides suggests an inflow of oxygenated seawater may have occurred in Hole C0015C. Foramini- 
fers possessing degraded surfaces and secondary mineral coatings were observed in a sample from 3.01 mbsf in Hole C0015B (Table T4). The foraminiferal diversity of this sample was generally consistent with that found in the surface mud samples examined from Holes C0014A and C0014B. Coccolithophorids were not observed in core catcher samples at Site C0015 using light or electron microscopy, with the exception of a single weathered coccolithophore on an iron oxide grain from $\sim 9.5 \mathrm{mbsf}$ (Fig. F5B). Destruction of coccolithophorids is expected in ironoxidizing environments because of acid generation associated with the hydrolysis of water. Examination of the iron oxide coating at high magnification revealed the presence of fibrous "oxides" possessing filaments that are consistent in size and shape with iron-oxidizing bacteria (Figs. F5B, F7).

\section{Petrology}

Only two cores were taken at Site C0015 (Cores 331C0015B-1H and 331-C0015C-1H), to a depth of 9.5 mbsf. Holes C0015B and C0015C were drilled $2 \mathrm{~m}$ apart and therefore can be considered a single drilled section for petrological interpretation. These cores lack hydrothermal alteration of the type seen at Sites C0013, C0015, and C0016. Except for the interval from 3.2 to 5.6 mbsf in Hole C0015B discussed below, the fine-grained sediment, sand, and pumiceous gravel we recovered show weak oxidation, expressed as yellow to brown coloration for the fine sediment and development of orange to brown iron oxide staining on some pumice fragments. Orange to brown botryoidal aggregates of Fe-Si oxyhydroxides 1-2 $\mathrm{mm}$ in size were also noted in Section 331C0013C-1H-3. Scanning electron microscope (SEM) imaging of this material (Fig. F6) showed a filamentous structure typical of oxyhydroxides associated with seafloor hydrothermal systems (e.g., Scott and Binns, 1995). No sulfide mineralization is associated with the oxidized material at Site C0015.

The interval from 3.2 to 5.07 mbsf in Hole C0015B comprises reduced olive-green mud with abundant biogenic fragments. This interval shows no evidence of oxidation. As expected, very fine grained framboidal pyrite, likely to have been formed by microbial processes, is found in trace quantities within this interval.

X-ray diffraction analysis of samples from Site C0015 (Table T5) identified a suite of minerals that are consistent with the lack of hydrothermal alteration at the site.

\section{Geochemistry}

\section{Interstitial water}

Five whole-round sections were processed for interstitial water at Site C0015 (Table T6). These sections were collected from immediately above or below microbiology-dedicated whole-round sections and were processed at ambient laboratory temperatures.

Only two cores were collected at Site C0015, so the deepest sample comes from only $8.8 \mathrm{mbsf}$. Four of the five samples have major element compositions close to those of seawater; the fifth has lower chloride but retains major ion ratios that are similar to seawater and so may have been inadvertently diluted during sample handling and processing (Figs. F8, F9, F10). Although minor and trace species do not necessarily follow this same pattern, their departures from seawater values could be driven by any number of in situ geochemical processes or sampling and analytical artifacts, so we have not interpreted those differences. Dissolved silica is likely enriched over bottom water concentrations, but this could be an artifact of processing temperature (Fig. F10). As only one sample had detectable ammonium levels (Table T6), we did not plot those data.

Whereas the uppermost 9 mbsf of sediment resembles seawater at Site C0015, this was not the case at Sites C0013 and C0014, which showed a strong hydrothermal influence even at this shallow depth.

\section{Headspace gas analysis}

Low concentrations of methane were detected in all samples at Site C0015, and ethane was not detected (Tables T7, T8). Methane at this site (Fig. F11) is much lower than at Sites C0013 and C0014, suggesting that a robust zone of microbial methanogenesis is not present at the shallow depths sampled (0-6.5 mbsf), in contrast with some of the other sites.

Hydrogen concentrations are low and variable (Table T7). Hydrogen was detected at 1.34, 2.75, 5.57, and 6.50 mbsf (Fig. F11) but was undetectable at the other depths sampled. In contrast to Sites C0013, C0014, and C0017, Site C0015 does not appear at present to support a robust microbial community, nor does it have any significant hydrothermal input.

\section{Sediment carbon, nitrogen, and sulfur composition}

Calcium carbonate $\left(\mathrm{CaCO}_{3}\right)$ calculated from inorganic carbon concentration ranges from 0.07 to 1.3 wt $\%$ in four of the six samples analyzed (Fig. F12; Ta- 
ble T9). The other two samples (from Sections 331C0015B-1H-1 and $1 \mathrm{H}-3$ ) have 21.4 and $38.7 \mathrm{wt} \%$ carbonate. The first is an oxidized brown mud with abundant foraminifers, and the second is a calcareous gravel containing numerous coral fragments (see "Lithostratigraphy").

Total organic carbon (TOC) ranges from 0.013 to $0.33 \mathrm{wt} \%$ (Fig. F13). Total nitrogen (TN) is below detection $(<0.001 \mathrm{wt} \%)$ in four samples and low in the other two. Total sulfur (TS) is also low, ranging from about 0.02 to $0.07 \mathrm{wt} \%$ except for one sample at 0.5 wt $\%$. The two horizons with higher carbonate also have higher TOC, consistent with a biogenic origin (from foraminifers and from corals). The one sample with higher sulfur (from Section 331-C0015B-1H-3) is a calcareous gravel, which also contains finegrained pyrite; TS is higher than TOC in this sample, consistent with some of the sulfur being diagenetic.

The generally low TOC indicates that both deposition and in situ production of organic matter are small. Sediment at Site C0015 is typical of pelagic sediment in this region and shows little or no influence of hydrothermal activity.

\section{Microbiology Total prokaryotic cell counts}

The abundance of microbial cells in subseafloor sediments at Site C0015 was evaluated by fluorescent microscopy using SYBR Green I as a fluorochrome dye. The maximum cell abundance was observed at 0.3 mbsf $\left(1.2 \times 10^{7}\right.$ cells $\left./ \mathrm{mL}\right)$. The microbial cell count decreased with depth and was below our detection limit of $\sim 1-4 \times 10^{6}$ cells $/ \mathrm{mL}$ at 5.6 mbsf. However, the cell count increased again to $8.8 \times 10^{6}$ cells $/ \mathrm{mL}$ sediment at $6.9 \mathrm{mbsf}$ and $4.8 \times 10^{6}$ cells $/ \mathrm{mL}$ at 8.8 mbsf (Fig. F14; Table T10).

\section{Contamination tests}

Fluorescent microspheres and perfluorocarbon tracer (PFT) were not detected in most of the core samples (Tables T11, T12), indicating that the cores were mostly uncontaminated. Exceptions were samples from 6.9 and $8.8 \mathrm{mbsf}$, which contained detectable amounts of both tracers and so appear to be contaminated with drilling fluid.

\section{Cultivation of iron-oxidizing bacteria}

Onboard cultivation/enrichment experiments for iron-oxidizing bacteria (FeOB) showed growth after $5-6$ days of incubation at room temperature $\left(21^{\circ} \mathrm{C}\right)$ for most of the samples inoculated (Table T13). Observation of petri plate coloration and turbidity after incubation (Fig. F15), though not effective for assessment of growth, did confirm the effectiveness of the GasPak in producing an anaerobic environment. Assessment of relative cell growth using epifluorescence microscopy yielded a variety of cellular morphologies and possible colonization strategies (Fig. F16). In Section 331-C0015B-1H-1, artificial seawater (ASW) media A, a long $(\sim 4 \mu \mathrm{m})$ rod-shaped bacterium can be seen contained within a twisted filament along with other, shorter rods at $\sim 2.5 \mu \mathrm{m}$. Section 331-C0015C-1H-3, ASW media B, also contained short rods that are often associated with larger particles. In Section 331-C0015C-1H-3, ASW media $\mathrm{A}$, rod-shaped bacteria colonize the surface of a large, dense particle. This observation could lend some insight into the colonization and weathering of the particle in Figure F17A.

Though no twisted iron oxide stalks, such as those created by Mariprofundus ferrooxydans, were observed in these enrichment experiments, SEM imaging revealed several possible sheathlike structures composed of iron oxides (Fig. F17). Imaging of original samples from Sample 331-C0015C-1H-3, 84-85 cm (see "Biostratigraphy"), showed extensive iron oxide filaments of putative biological origin. Also, several putative bifurcated iron oxide twisted stalks were observed under epifluorescence microscopy, though these structures were not associated with cells (Fig. F18).

\section{Conclusions}

As was the case at Sites C0013 and C0014, cell abundances at Site C0015 were significantly lower than those found in previous Ocean Drilling Program/ IODP sites on continental margins (Parkes et al., 1994, 2000; D'Hondt et al., 2004), despite the location of the Iheya North field in a backarc basin associated with a continental margin. The generally low microbial abundance in the subseafloor at the Iheya North field may be associated with low primary production in the surface ocean and/or low influx of terrigenous organic matter in the middle Okinawa Trough, as previously suggested for the Brazos-Trinity Basin IV and the Mars-Ursa Basin in the Gulf of Mexico continental margin drilled by IODP Expedition 308 (Holes U1319A, U1320A, U1322B, and U1324B) (Nunoura et al., 2009).

In the deeper sediments at Site C0015 the cell count increased again. Although depth profiles of interstitial water chemistry and dissolved gas concentrations (see "Geochemistry") are relatively invariant at Site C0015, there are lithological differences between the surficial and the deeper sediment. Layers with low cell abundances at 3.4 and 5.6 mbsf consist of pelagic clay, whereas those with higher cell counts 
at 6.9 and 8.8 mbsf occur in sandy layers (see "Lithostratigraphy"). The depth profile of cell abundance at Site C0015 may thus be explained by the physical properties of the sediments such as porosity, as has been pointed out in previous studies (Schmidt et al., 1998; Zhang et al., 1998; Parkes et al., 2000; Inagaki et al., 2003; Rebata-Landa and Santamarina, 2006).

Samples from Site C0015 represent the deepest relatively pristine inoculum that showed positive growth for putative FeOB for any site during Expedition 331. Contamination was below our detection limit. With increasing depth, relative growth shifted from a preference toward a microaerophilic environment to a more anaerobic environment. The detection of FeOB at this "cooler" site is consistent with previous detection of $\mathrm{FeOB}$ in other low-temperature hydrothermal vent systems (Rassa et al., 2009).

\section{Physical properties}

Physical property measurements were made at Site C0015 to nondestructively characterize lithologic units and states of sediment consolidation.

\section{Density and porosity}

Bulk density values at Site C0015 were determined from both gamma ray attenuation (GRA) measurements on whole cores (with the multisensor core logger for whole-round samples [MSCL-W]) and moisture and density (MAD) measurements on discrete samples from the working halves of split cores (see "Physical properties" in Expedition 331 Scientists, 2011b). A total of seven discrete samples were analyzed for MAD (five from Hole C0015B and two from Hole C0015C). Wet bulk density is essentially constant with depth (Fig. F19), whether determined from MAD measurements or from GRA. GRA-derived bulk density is generally lower than discrete MAD bulk density and exhibits a larger degree of scatter but the same overall pattern (Fig. F19). This measurement is expected of GRA-derived density, as GRA is very sensitive to incompletely filled core liners and the presence of voids and cracks.

The average bulk density in Holes C0015B and C0015C is $1.6 \pm 0.1 \mathrm{~g} / \mathrm{cm}^{3}$ (Table T14).

Grain density was determined from discrete MAD measurements. Grain density is also nearly constant with depth (average $=2.61 \mathrm{~g} / \mathrm{cm}^{3}$ ) (Fig. F19; Table T14) with a slight excursion toward higher grain densities $\left(\sim 2.8 \mathrm{~g} / \mathrm{cm}^{3}\right)$ at $\sim 4 \mathrm{mbsf}$.

Porosity was also calculated from MAD measurements. MAD-derived porosity is generally quite high (40\%-60\%) and decreases with depth in Hole C0015B (Fig. F20). In general, density and porosity results from the two holes (C0015B and C0015C) at Site C0015 reveal a consistent pattern with depth; however, the sparsity of data from this site prevents any firm conclusions.

\section{Electrical resistivity (formation factor)}

Formation factor is a measure of the connected pore space within the sediments and is used to calculate the bulk sediment diffusion coefficient. Electrical impedance measurements were made at eight specific locations (six from Hole C0015B and two from Hole C0015C). Formation factors calculated for Site C0015 ranged from $\sim 3$ to 11 . Formation factor is constant with depth (Fig. F21) in Hole C0015B with an average value of $3.7 \pm 0.42$ (Table T14). The two values measured in Hole C0014C are 10.9 and 5.8, at 6.7 and 8.8 mbsf, respectively.

\section{Thermal conductivity}

Thermal conductivity measurements were conducted on whole-round cores. A total of eight measurements were made at this site (seven from Hole C0015B and one from Hole C0015C). Thermal conductivity at Site C0015 is generally low and ranges from $0.7 \mathrm{~W} /(\mathrm{m} \cdot \mathrm{K})$ at $\sim 1.5 \mathrm{mbsf}$ to $1.1 \mathrm{~W} /(\mathrm{m} \cdot \mathrm{K})$ at $\sim 4.5$ mbsf (Fig. F22). The average thermal conductivity for Site C0015 is $0.89 \pm 0.15 \mathrm{~W} /(\mathrm{m} \cdot \mathrm{K})$ (Table T14). In general, thermal conductivity is relatively constant with depth.

\section{MSCL-I and MSCL-C imaging}

MSCL-derived core images and color analyses are presented in the visual core descriptions (VCDs).

\section{MSCL-W derived electrical resistivity}

MSCL-W based resistivity data are generally constant and low $(\sim 1 \Omega \mathrm{m})$, but there is region of high resistivity $(5-30 \Omega \mathrm{m})$ at $\sim 7.5 \mathrm{mbsf}$. There is no obvious relationship with the discrete measurements of formation factor (Fig. F23 versus Fig. F21).

\section{References}

D’Hondt, S., Jørgensen, B.B., Miller, D.J., Batzke, A., Blake, R., Cragg, B.A., Cypionka, H., Dickens, G.R., Ferdelman, T., Hinrichs, K.-U., Holm, N.G., Mitterer, R., Spivack, A., Wang, G., Bekins, B., Engelen, B., Ford, K., Gettemy, G., Rutherford, S.D., Sass, H., Skilbeck, C.G., Aiello, I.W., Guerin, G., House, C.H., Inagaki, F., Meister, P., Naehr, T., Niitsuma, S., Parkes, R.J., Schippers, A., Smith, D.C., Teske, A., Wiegel, J., Naranjo Padillo, C., and Solis Acosta, J.L., 2004. Distributions of microbial activities in deep subseafloor sediments. Science, 306(5705):22162221. doi:10.1126/science. 1101155 
Expedition 331 Scientists, 2011a. Expedition 331 summary. In Takai, K., Mottl, M.J., Nielsen, S.H., and the Expedition 331 Scientists, Proc. IODP, 331: Tokyo (Integrated Ocean Drilling Program Management International, Inc.). doi:10.2204/iodp.proc.331.101.2011

Expedition 331 Scientists, 2011b. Methods. In Takai, K., Mottl, M.J., Nielsen, S.H., and the Expedition 331 Scientists, Proc. IODP, 331: Tokyo (Integrated Ocean Drilling Program Management International, Inc.). doi:10.2204/iodp.proc.331.102.2011

Expedition 331 Scientists, 2011c. Site C0013. In Takai, K., Mottl, M.J., Nielsen, S.H., and the Expedition 331 Scientists, Proc. IODP, 331: Tokyo (Integrated Ocean Drilling Program Management International, Inc.). doi:10.2204/iodp.proc.331.103.2011

Inagaki, F., Suzuki, M., Takai, K., Oida, H., Sakamoto, T., Aoki, K., Nealson, K.H., and Horikoshi, K., 2003. Microbial communities associated with geological horizons in coastal subseafloor sediments from the Sea of Okhotsk. Appl. Environ. Microbiol., 69(12):7224-7235. doi:10.1128/AEM.69.12.7224-7235.2003

Kato, Y., 1987. Woody pumice generated with submarine eruption. Chishitsugaku Zasshi, 93:11-20.

Nunoura, T., Soffientino, B., Blazejak, A., Kakuta, J., Oida, H., Schippers, A., and Takai, K., 2009. Subseafloor microbial communities associated with rapid turbidite deposition in the Gulf of Mexico continental slope (IODP Expedition 308). FEMS Microbiol. Ecol., 69(3):410424. doi:10.1111/j.1574-6941.2009.00718.x

Parkes, R.J., Cragg, B.A., Bale, S.J., Getliff, J.M., Goodman, K., Rochelle, P.A., Fry, J.C., Weightman, A.J., and Harvey, S.M., 1994. Deep bacterial biosphere in Pacific Ocean sediments. Nature (London, U. K.), 371(6496):410-413. doi:10.1038/371410a0

Parkes, R.J., Cragg, B.A., and Wellsbury, P., 2000. Recent studies on bacterial populations and processes in sub- seafloor sediments: a review. Hydrogeol. J., 8(1):11-28. doi:10.1007/PL00010971

Rassa, A.C., McAllister, S.M., Safran, S.A., and Moyer, C.L., 2009. Zeta-Proteobacteria dominate the colonization and formation of microbial mats in low-temperature hydrothermal vents at Loihi Seamount, Hawaii. Geomicrobiol. J., 26(8):623-638.

Rebata-Landa, V., and Santamarina, J.C., 2006. Mechanical limits to microbial activity in deep sediments. Geochem., Geophys., Geosyst., 7(11):Q11006-Q11017. doi:10.1029/ 2006GC001355

Schmidt, J.L., Deming, J.W., Jumars, P.A., and Keil, R.G., 1998. Constancy of bacterial abundance in surficial marine sediments. Limnol. Oceanogr., 43(5):976-982. doi:10.4319/1o.1998.43.5.0976

Schmincke H.-U., 2004. Volcanism: Berlin (Springer-Verlag).

Scott, S.D., and Binns, R.A., 1995. Hydrothermal processes and contrasting styles of mineralization in the western Woodlark and eastern Manus basins of the western Pacific. In Parson, L.M., Walker, C.L., and Dixon, D.R. (Eds.), Hydrothermal Vents and Processes. Geol. Soc. Spec. Publ., 87:191-205. doi:10.1144/

GSL.SP.1995.087.01.16

Walker, R.G., 1992. Turbidites and submarine fans. In Walker, R.G., and James, N.P. (Eds.), Facies Models: Response to Sea Level Change (2nd ed.): St. John's, Newfoundland (Geol. Assoc. Can.), 239-264.

Zhang, C., Palumbo, A.V., Phelps, T.J., Beauchamp, J.J., Brockman, F.J., Murray, C.J., Parsons, B.S., and Swift, D.J.P., 1998. Grain size and depth constraints on microbial variability in coastal plain subsurface sediments. Geomicrobiol. J., 15(3):171-185. doi:10.1080/ 01490459809378074

Publication: 4 October 2011 MS 331-105 
Figure F1. Three-dimensional extension of negative polarity sequences beneath the hill west of the Iheya North hydrothermal field. The eastern end of the sequences converges to the hydrothermal vent sites. The other end continues to the northern and western area within the subseafloor basin-filling sediments. These sequences may serve as the dominant hydrothermal fluid migration path for the high-temperature vents of the Iheya North hydrothermal field.

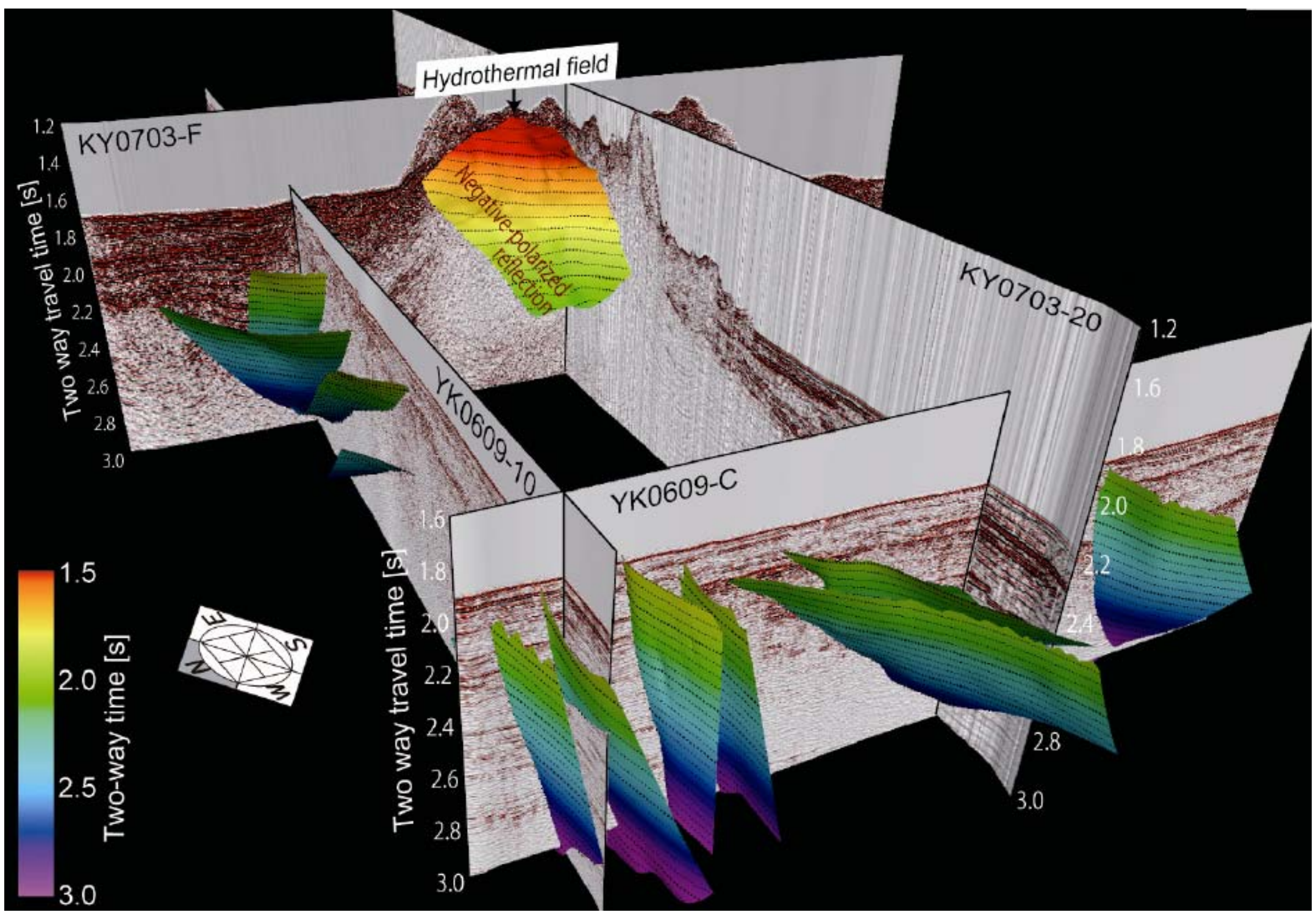


Figure F2. Bathymetric map, Site C0015.

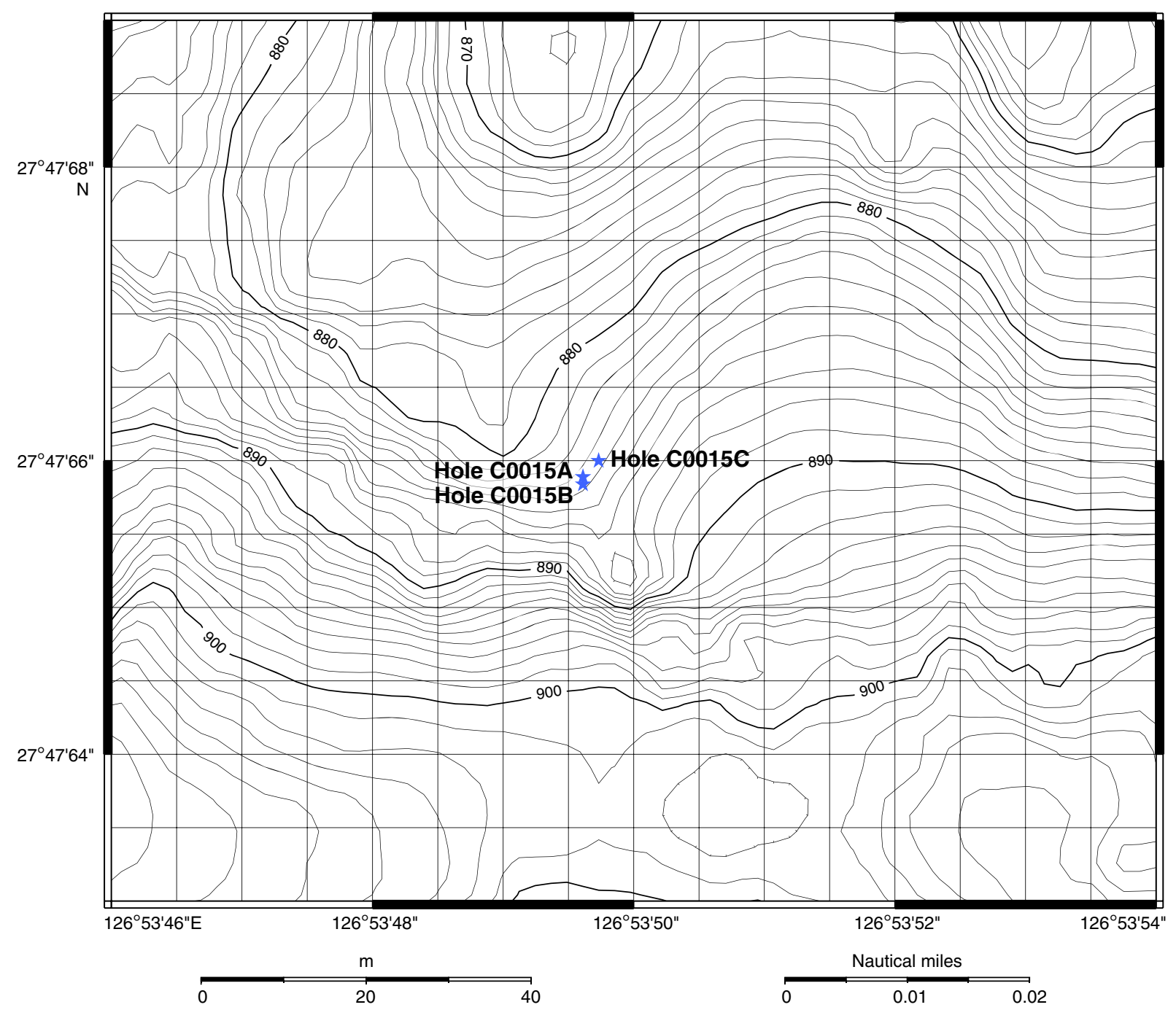


Figure F3. Sedimentary logs for Site C0015 synthesized from lithologies inferred from visual core description, continuous logs of $P$-wave velocity, electrical resistivity, and grain density. Recognition of sedimentary contacts was aided by hand specimen description and X-ray CT imaging.

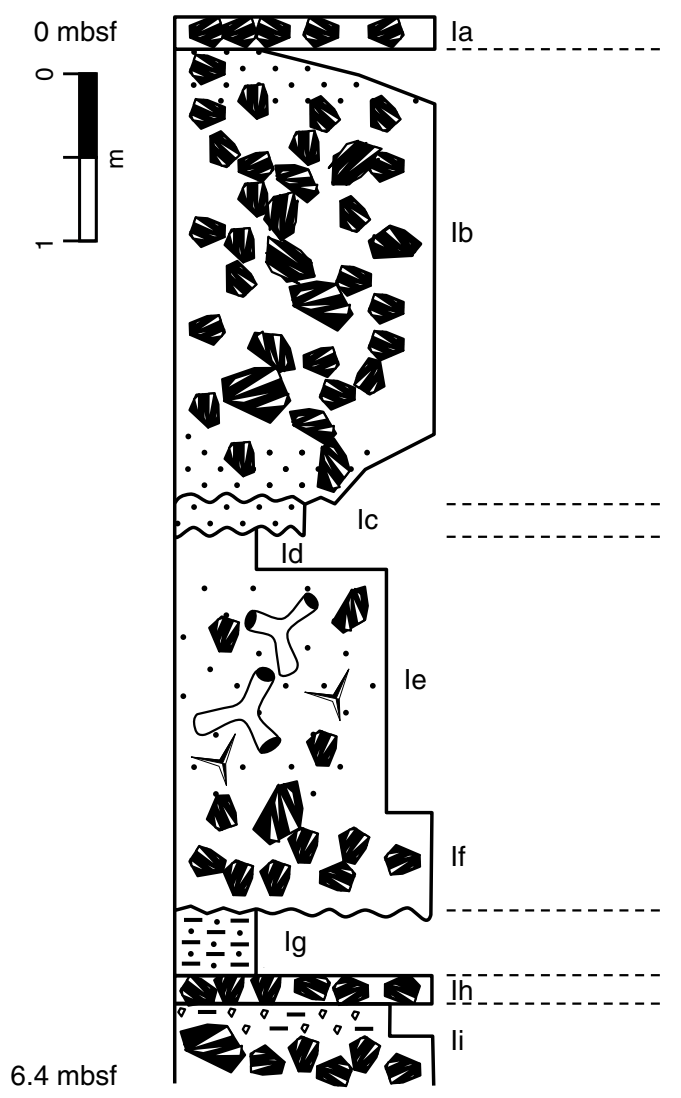

\section{Hole C0015B}

la) Clast-supported coarse-grained angular woody pumice gravel

Ib) Inverse to normally graded clast-supported coarse-grained angular woody pumice gravel

Ic) Unconsolidated medium-grained, well-sorted foraminiferal sand

Id) Silty foraminiferal sand

le) Matrix-supported bioclastic gravel with $20 \%$ coral fragment and rare clasts of woody pumice in a poorly sorted mud to coarse quartz sand matrix

If) Subrounded woody pumice gravel

Ig) Mud with pumiceous silt laminae

Ih) Clast-supported coarse-grained angular woody pumice gravel

li) Pumiceous grit grading to gravel at base

Hole C0015C

lj) Unconsolidated medium-grained, well-sorted, well-rounded quartz sand

Ik) Clast-supported coarse-grained angular woody pumice gravel

II) Unconsolidated medium-grained, well-sorted, well-rounded quartz sand-highly disrupted by drilling

Im) Well-sorted quartz-pumice grit

In) Clast-supported coarse-grained angular pumice gravel

$\because \because$ Sand
$\therefore \div \div$ Sepositional
contact
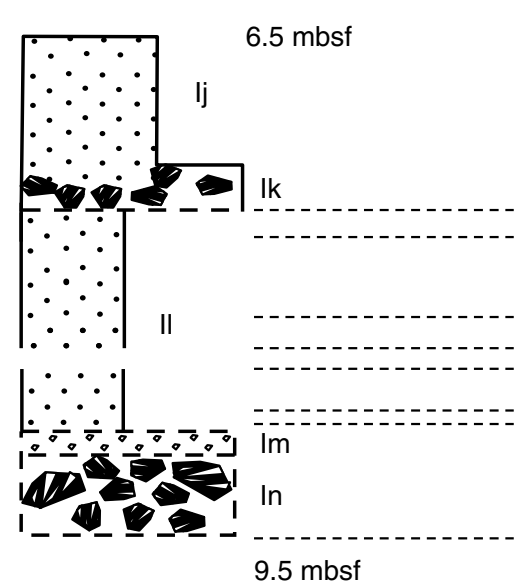
Figure F4. Photograph of outcrop of volcanic debris flow comprising fragmented lavas and pumice, Lower Arguineguin canyon, Gran Canaria, Canary Islands. Note lack of continuity of pumice breccia even for the thickest units. In this subaerially weathered outcrop, correlative horizons show as a red weathering product. Taken from Schmincke (2004). Human figure for scale.

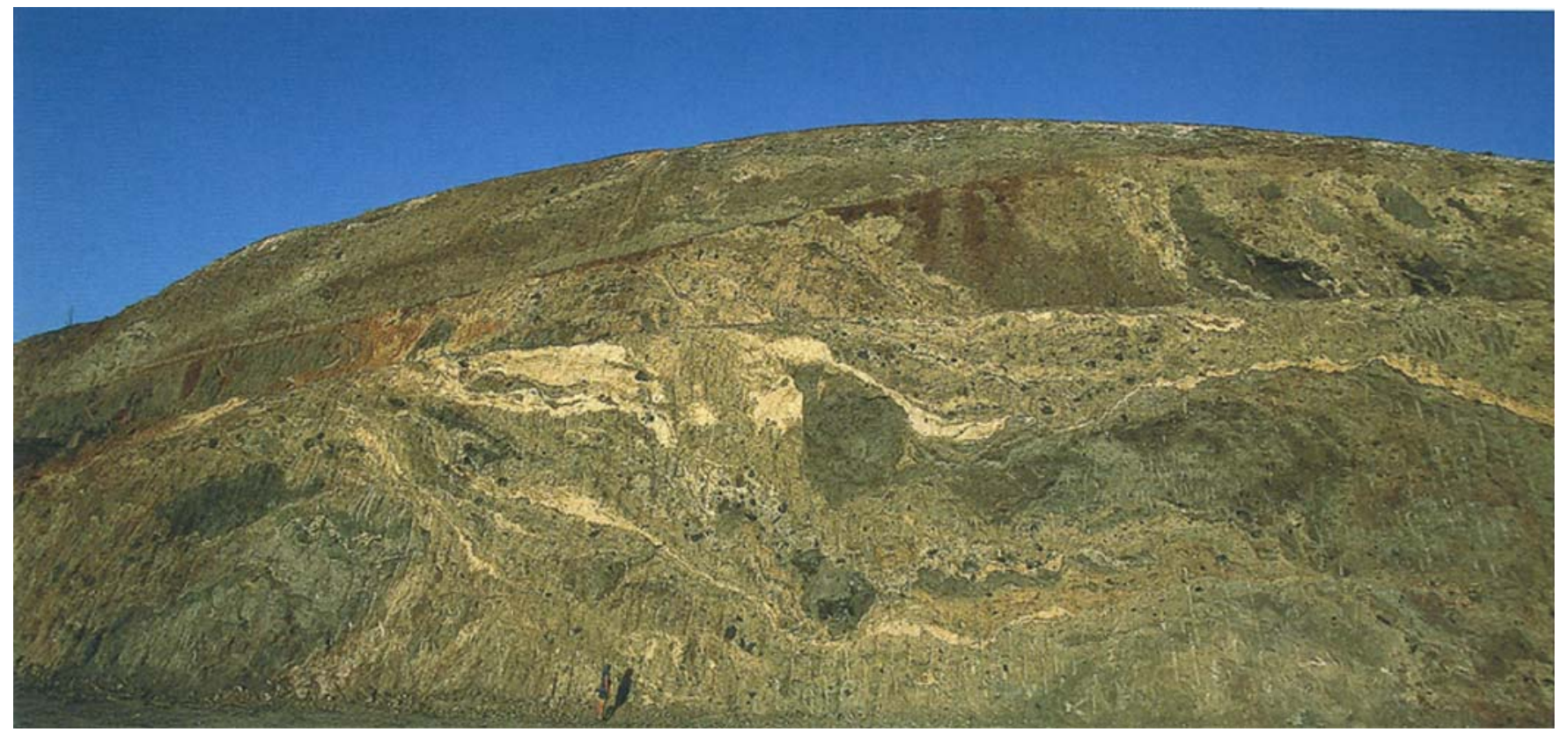


Figure F5. A. SEM photomicrograph of an iron oxide sample picked from Sample 331-C0015C-1H-3, 84-85 cm ( 9.5 mbsf). High-resolution images of the areas indicated by the two arrows in panel A are found in Figure F7. B. At high magnification, an individual, sad, weathered coccolithophore was observed (arrow).

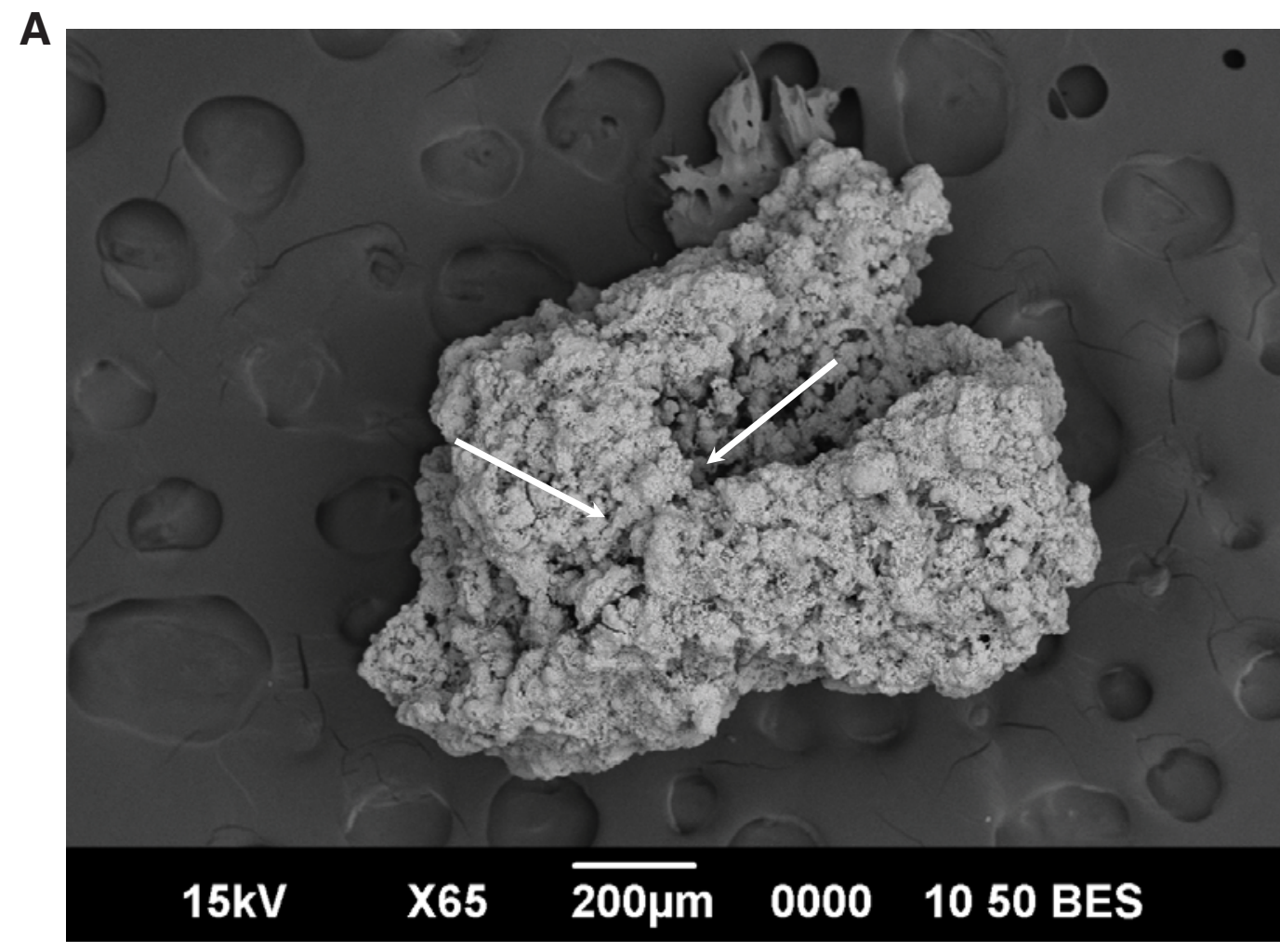

B

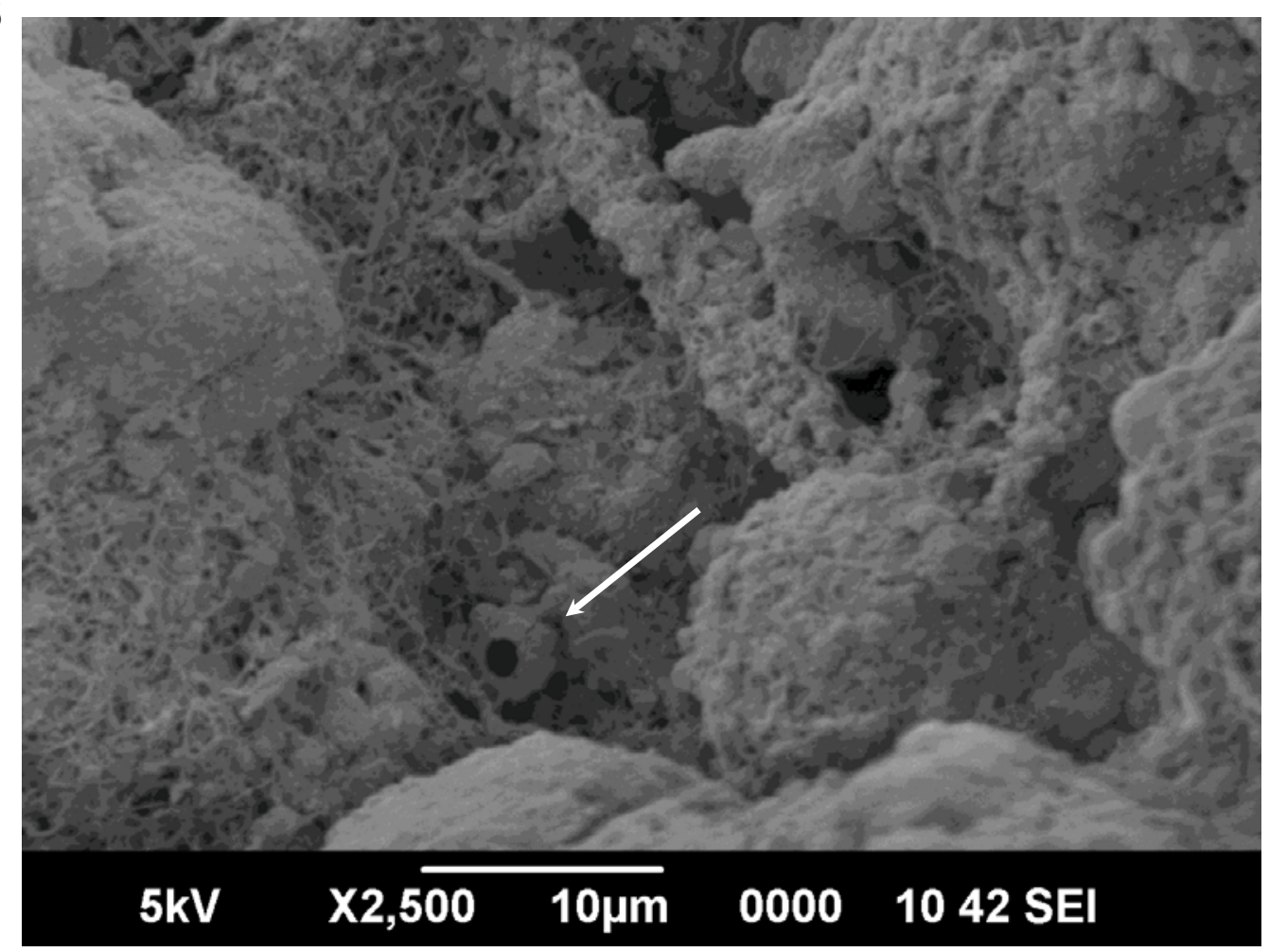


Figure F6. SEM photomicrographs of Fe-Si oxyhydroxide (Sample 331-C0015C-1H-3, 84.0-85.0 cm). A. Backscattered electron image showing the botryoidal form of the aggregate. B. High-magnification image showing filamentous fine structure.

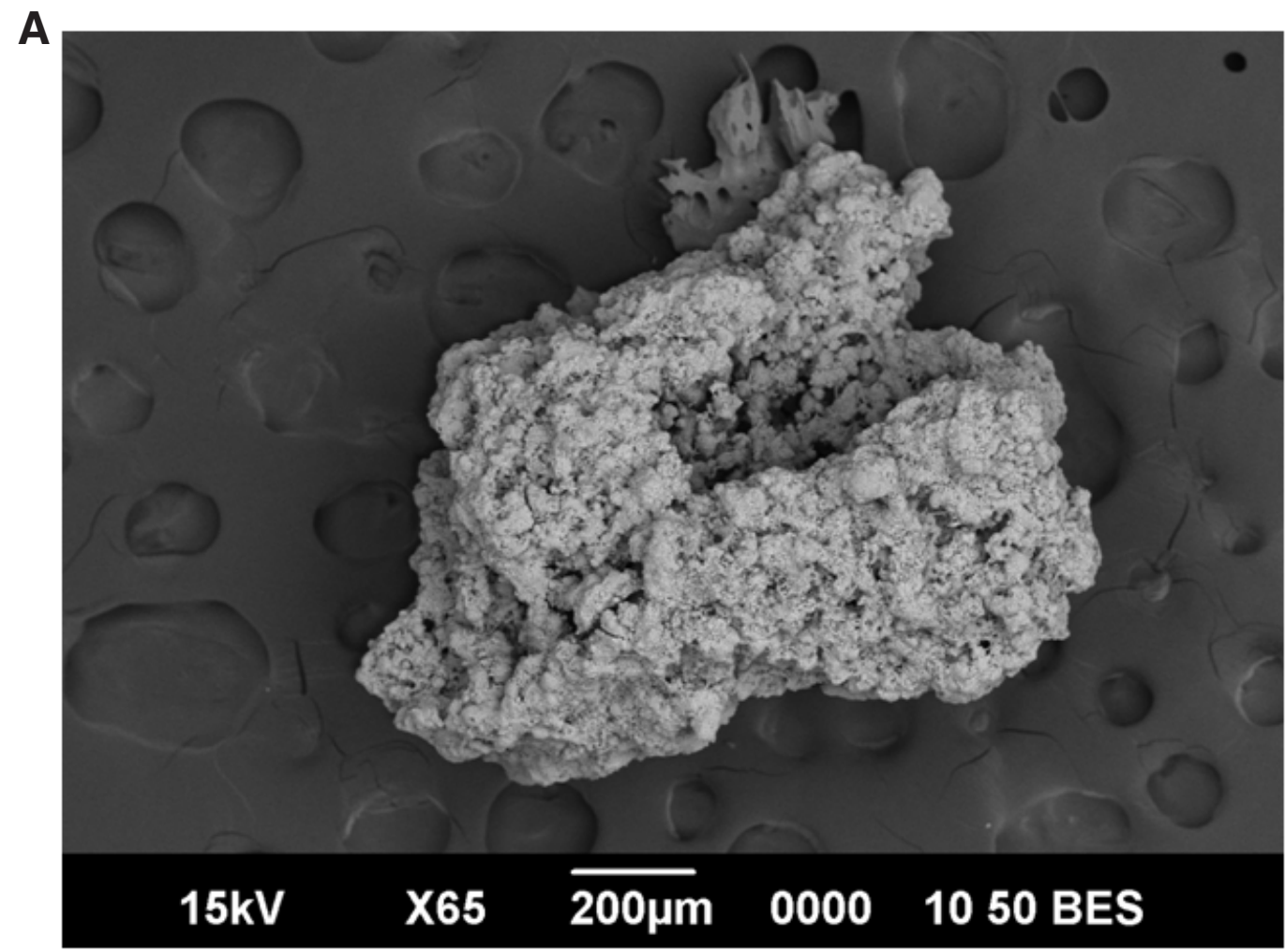

B

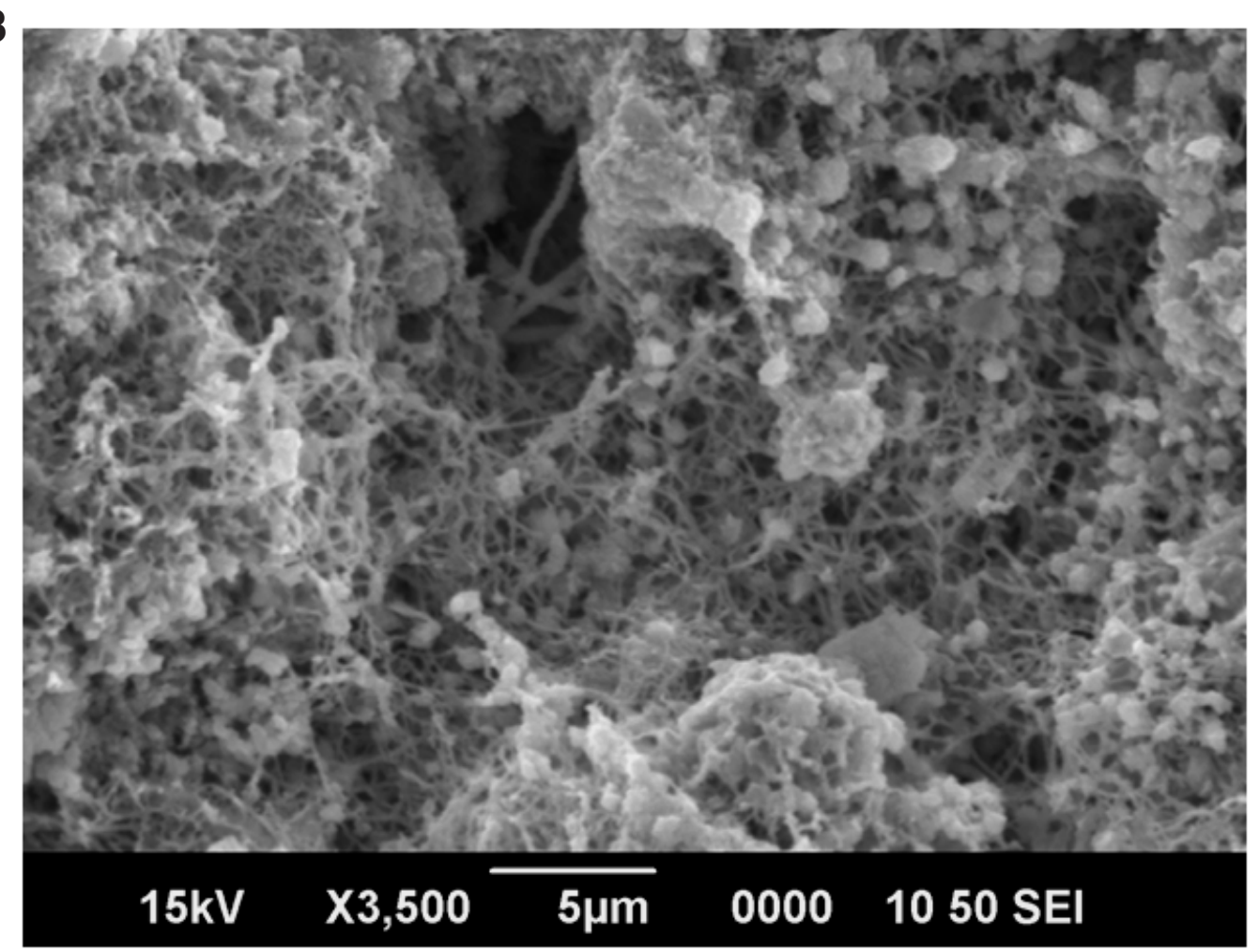


Figure F7. A-B. High-resolution SEM photomicrographs of the iron oxide sample shown in Figure F5. Note the filamentous texture of the iron oxide coating the surface of the grain; some of the filaments (arrow) have a size and shape consistent with that of an iron-oxidizing bacterium.
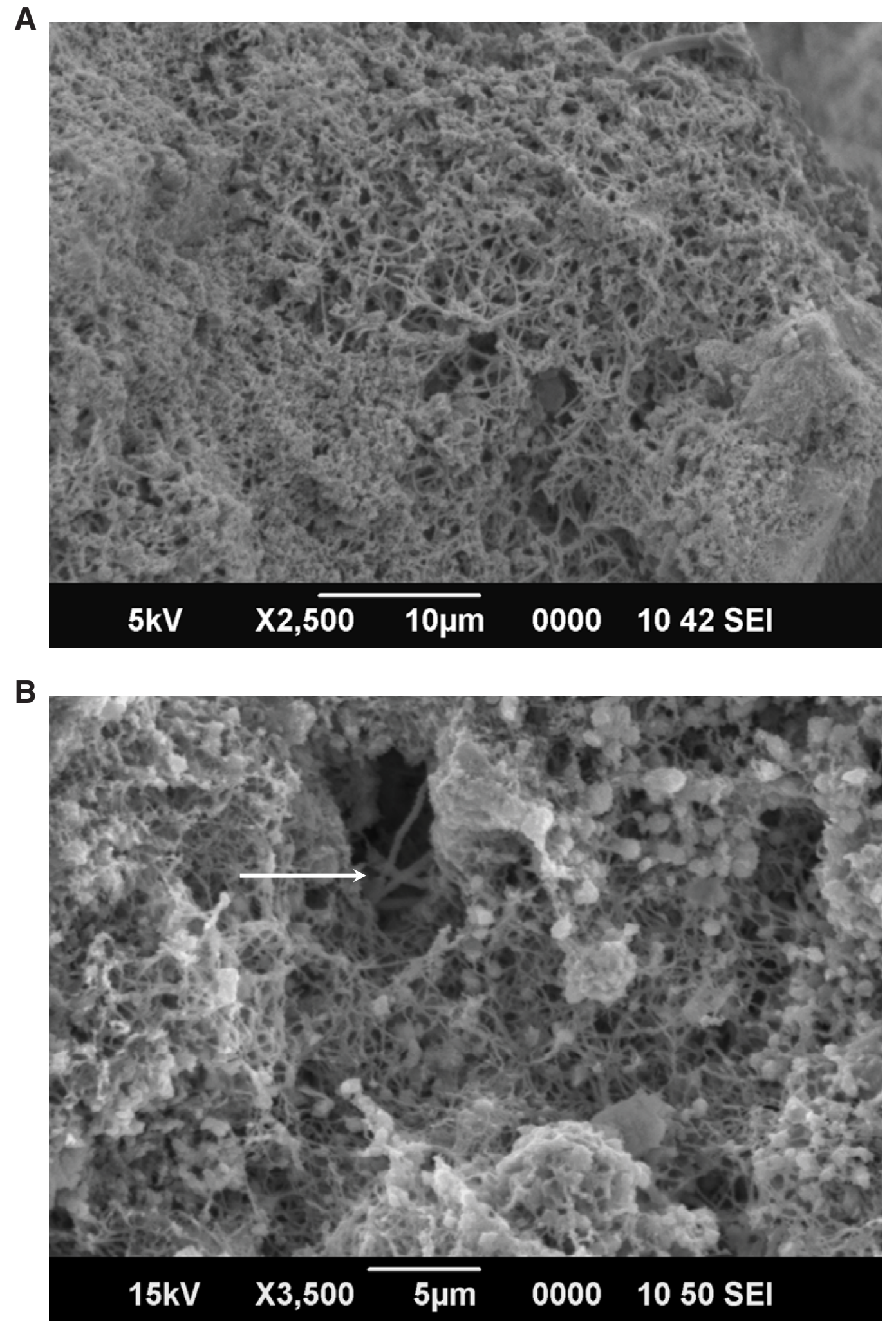
Figure F8. Depth profiles for sodium, sodium to chloride ratio, potassium, magnesium, and calcium in interstitial water at Site C0015. Arrows show seawater values, as does the dashed line for the $\mathrm{Na} / \mathrm{Cl}$ ratio.

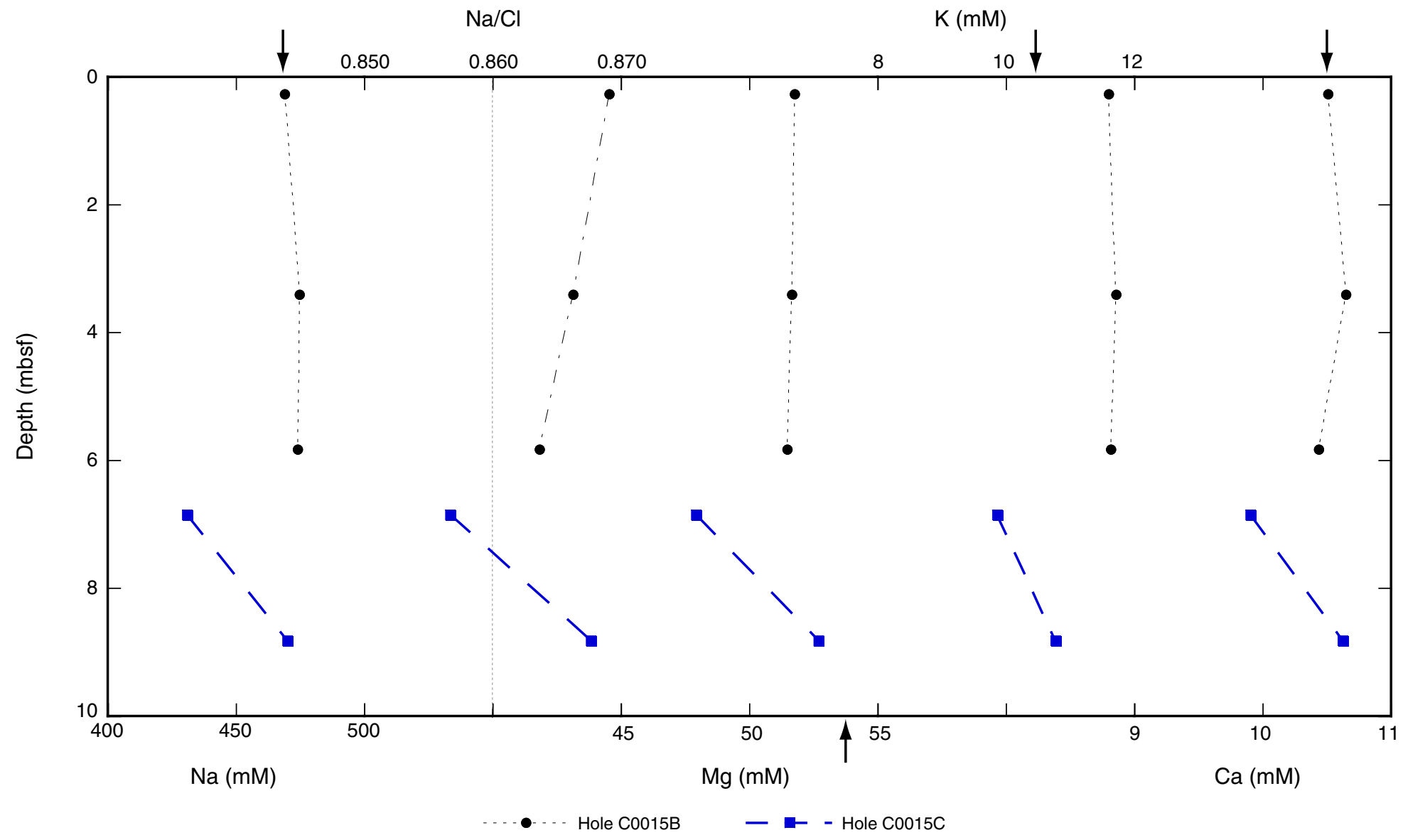


Figure F9. Depth profiles for chloride, bromide, and sulfate in interstitial water from Site C0015. Arrows show concentration in seawater.

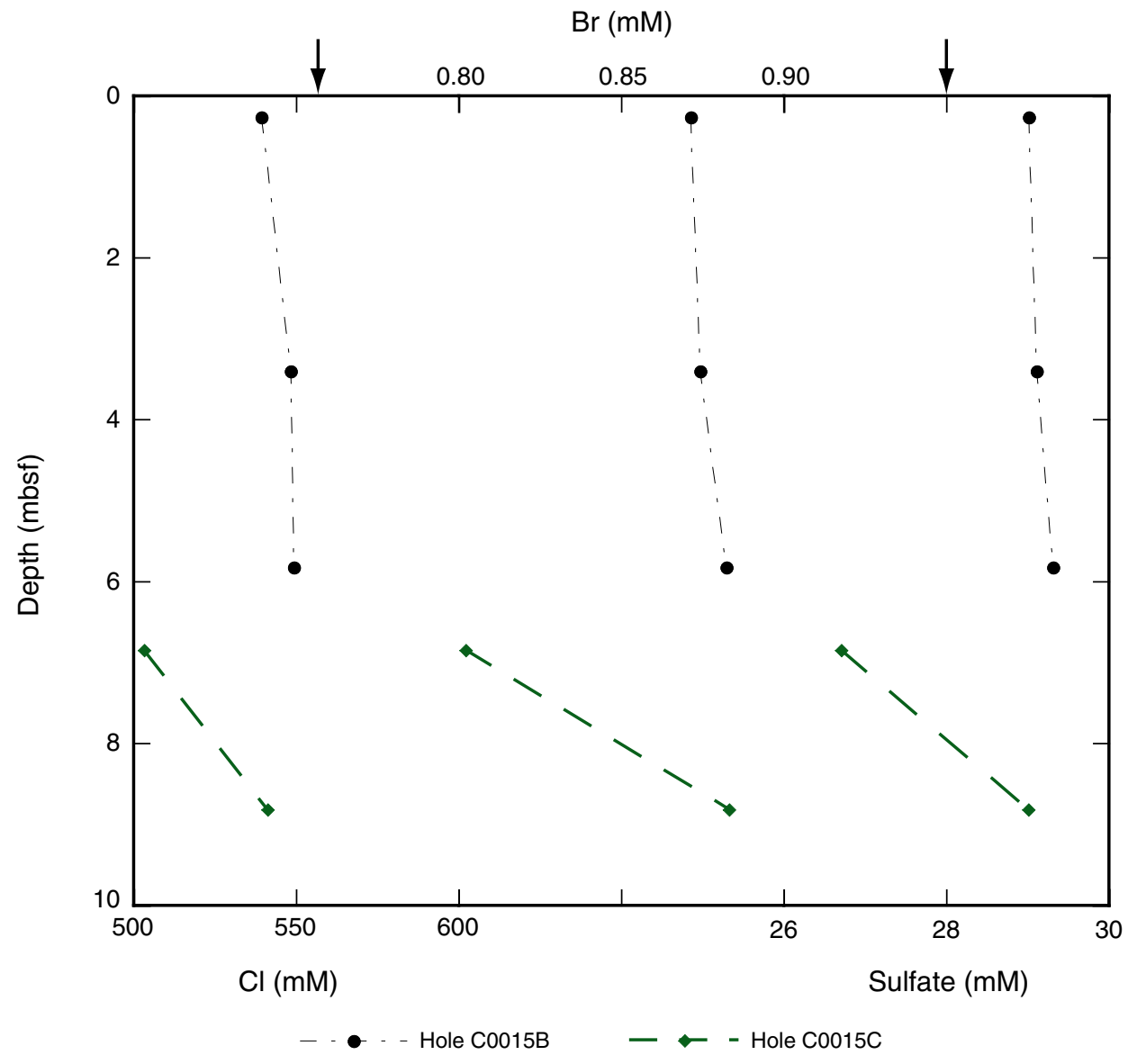


Figure F10. Depth profiles for alkalinity, silicon (measured colorimetrically), and phosphate in interstitial water at Site C0015.

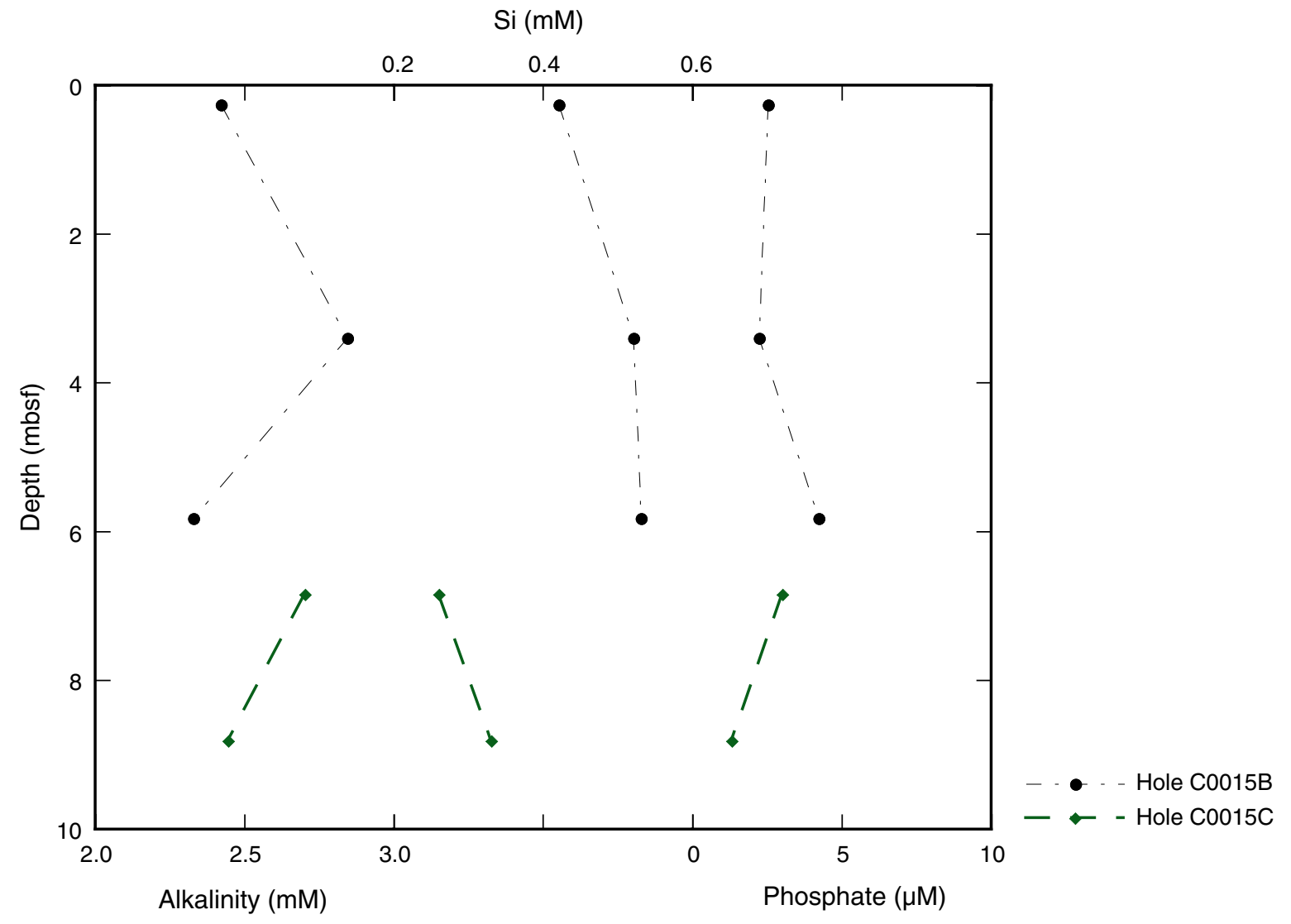


Figure F11. Depth profiles of methane concentration in safety gas (HS) samples $(\mu \mathrm{M})$ and methane ( $\mu \mathrm{M})$ and hydrogen (nM) concentrations in science gas samples.

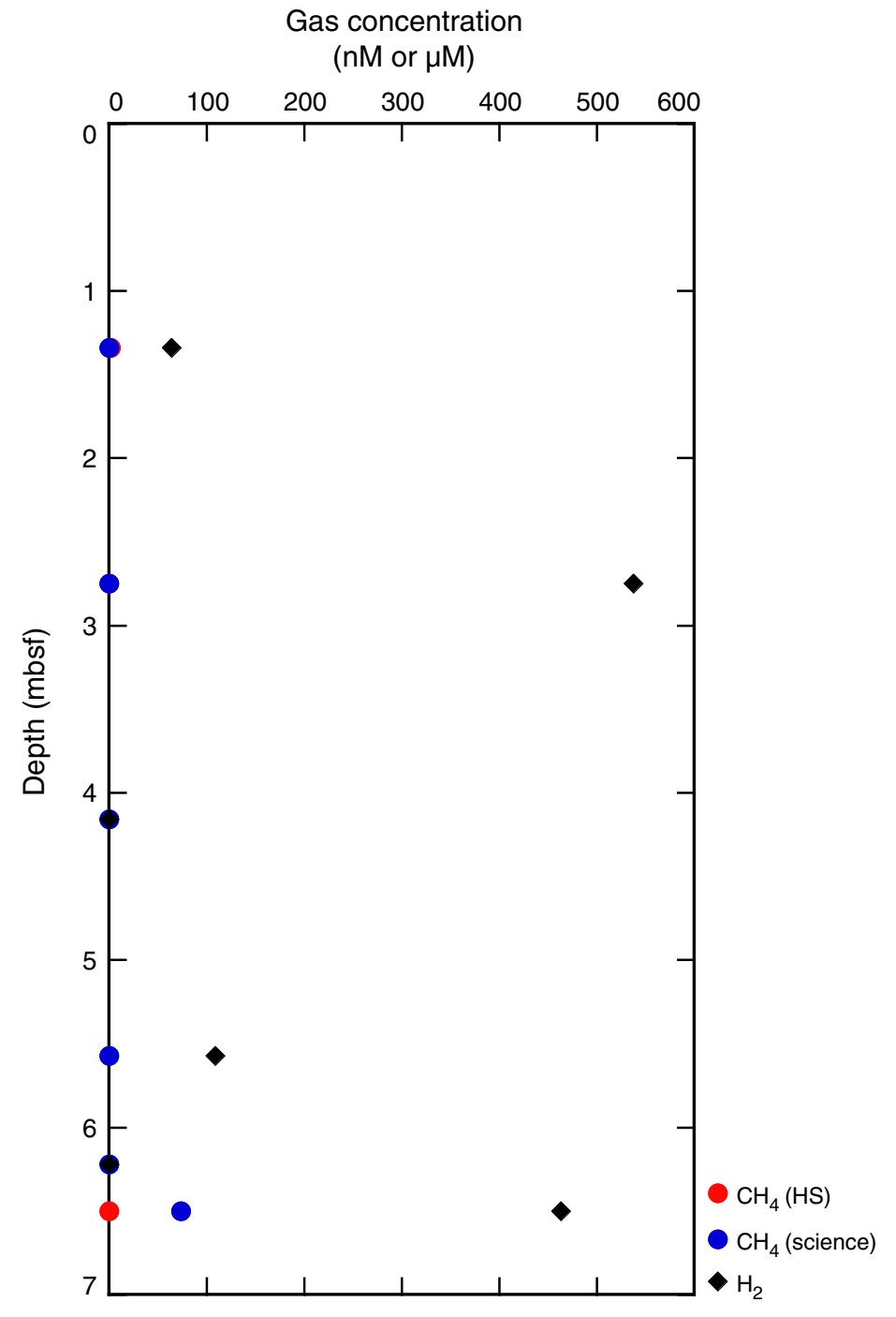


Figure F12. Depth profile of $\mathrm{CaCO}_{3}$ in sediment at Site $\mathrm{C} 0015$.

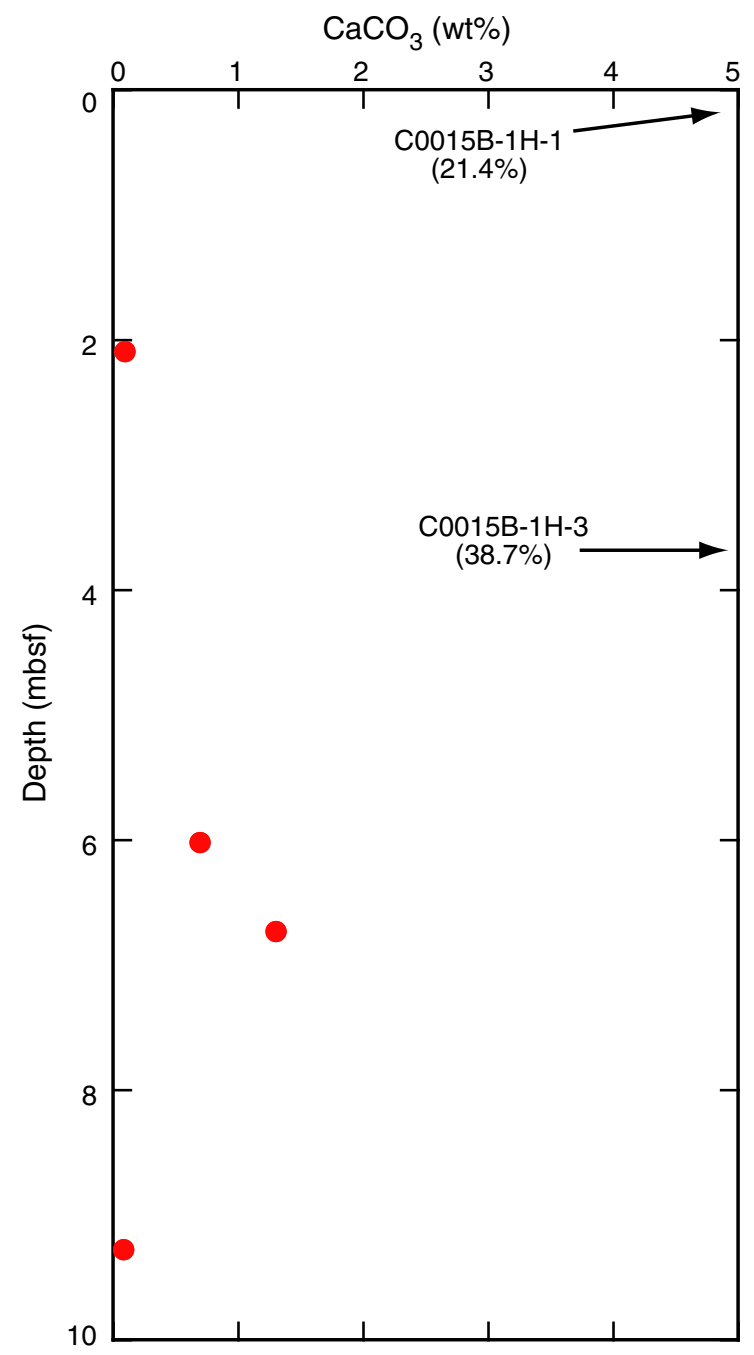


Figure F13. Depth profile of total organic carbon (TOC), total nitrogen (TN), and total sulfur (TS) in sediment at Site C0015.

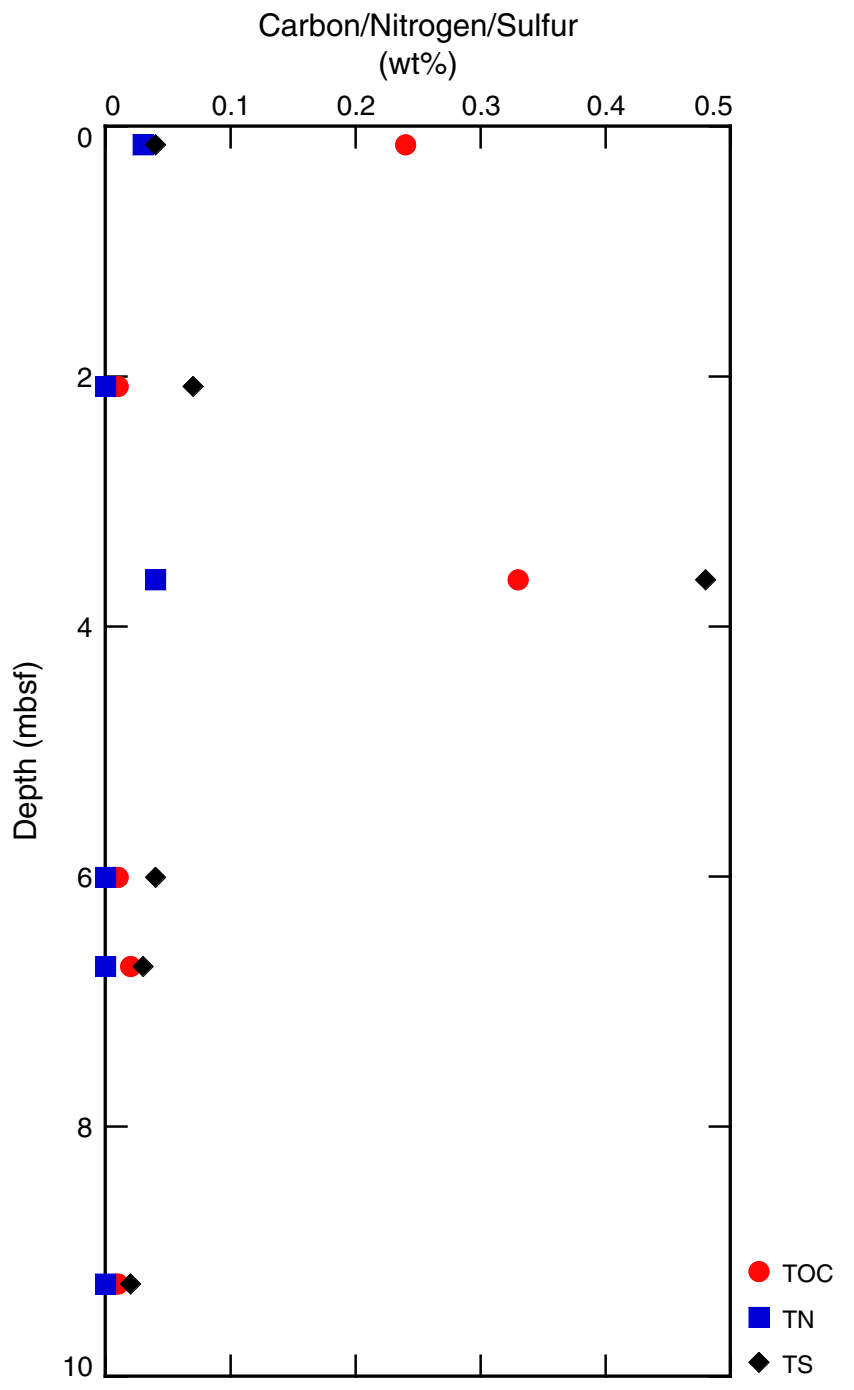


Figure F14. Plot of microbial cell counts at Site C0015. Sediment samples from above 5.6 mbsf were taken from Hole C0015B and those below 6.9 mbsf from Hole C0015C. The open circle indicates that cell counts are below our limit of detection (Expedition 331 Scientists, 2011b).

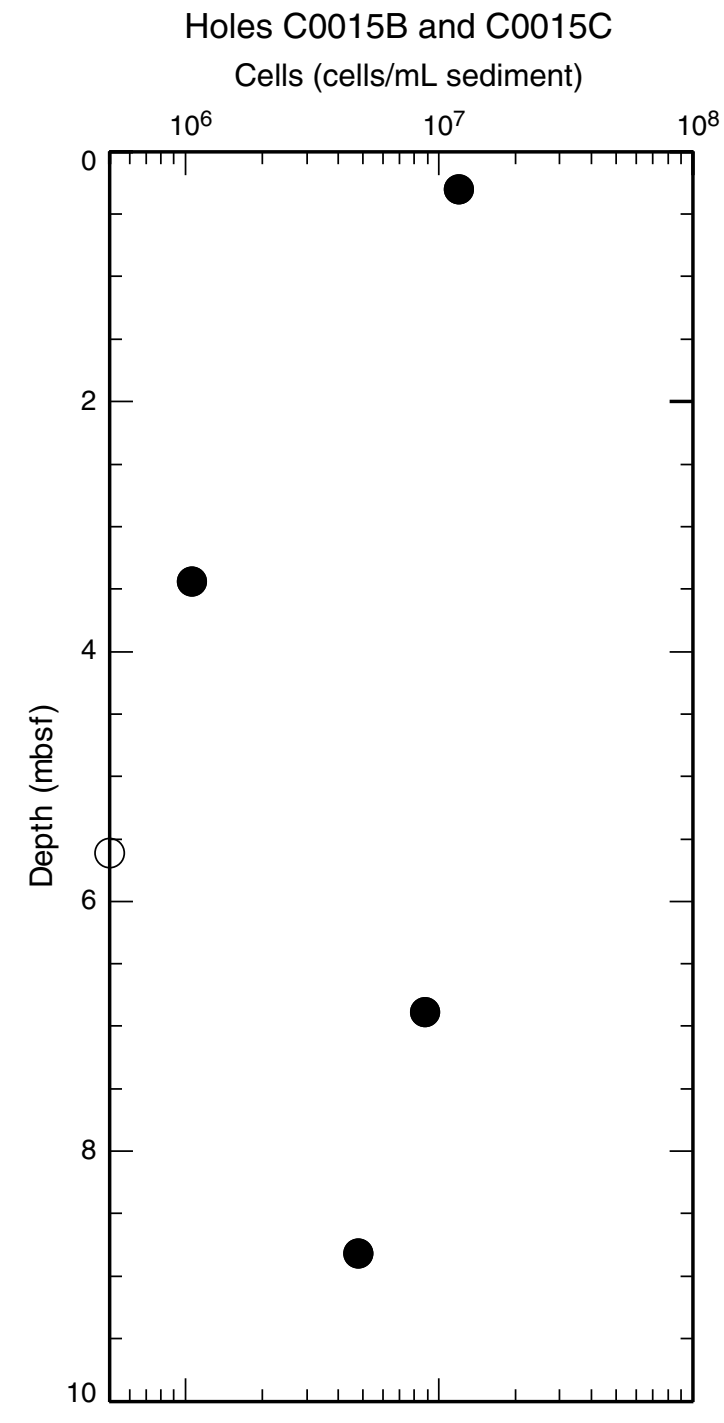


Figure F15. Photographs of petri plates postincubation $\left(\sim 21^{\circ} \mathrm{C}\right)$ showing (A) microaerophilic ASW media A and (B) anaerobic ASW media B FeOB cultivation experiments for Sample 331-C0015C-H-3, 25-35 cm, both shown to be positive for growth by epifluorescence microscopy using SYBR Green I.
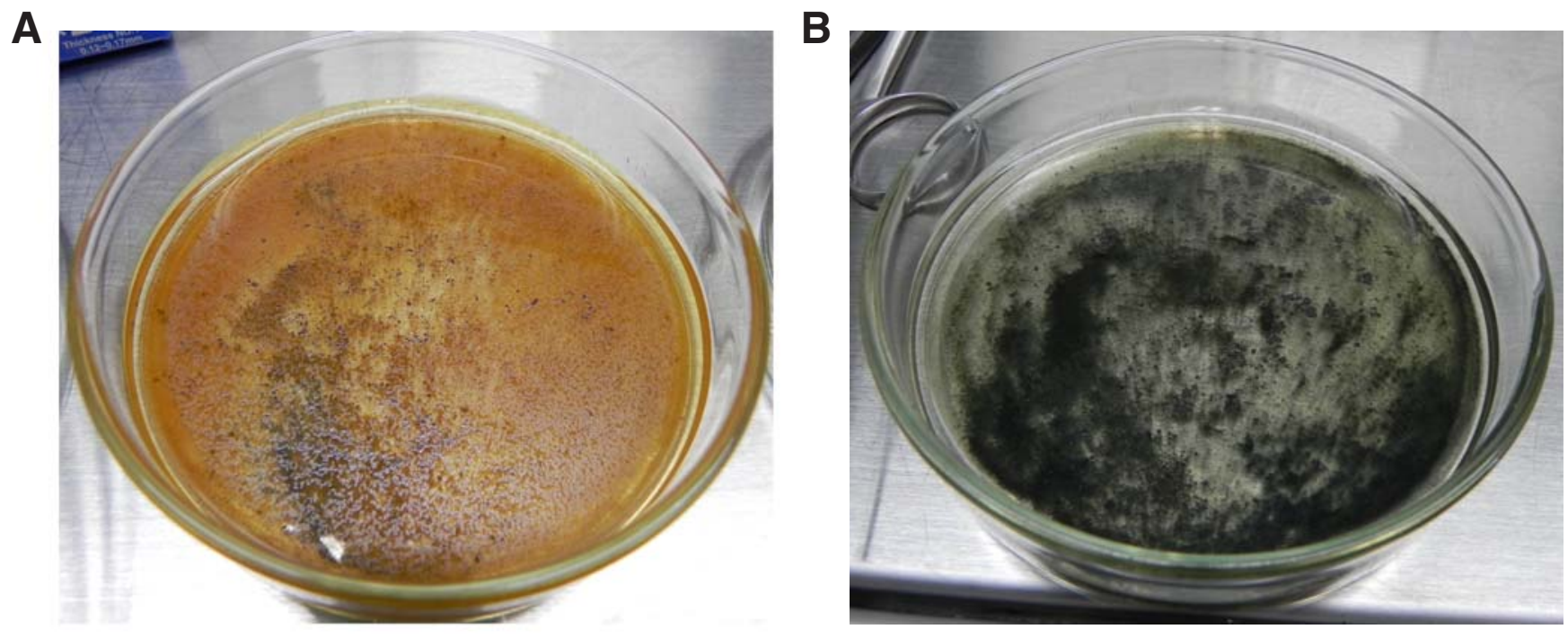
Figure F16. Paired photomicrograph images using epifluorescent (A, C, E), phase contrast (B, F), and brightfield (D) microscopy. Arrows indicate the location of putative FeOB. A, B. Section 331-C0015B-1H-1, ASW media A. C, D. Section 331-C0015C-1H-3, ASW media A. E, F. Section 331-C0015C-1H-3, ASW media B.

A

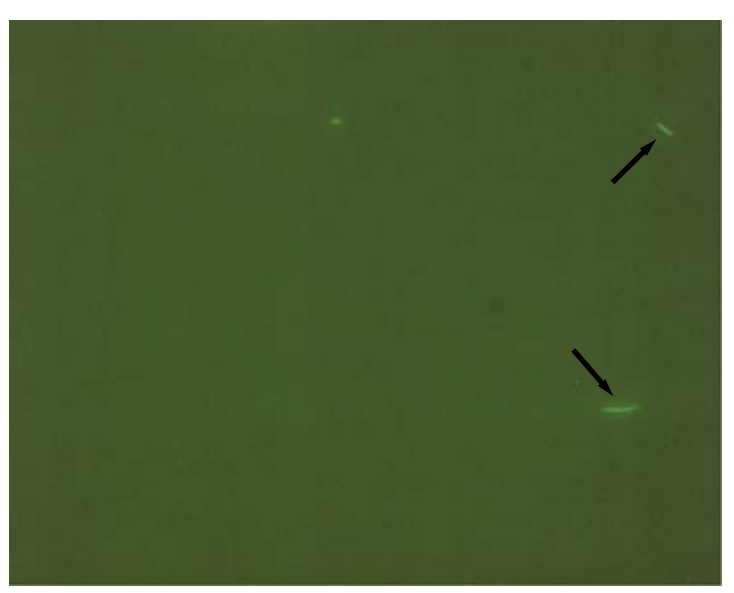

C

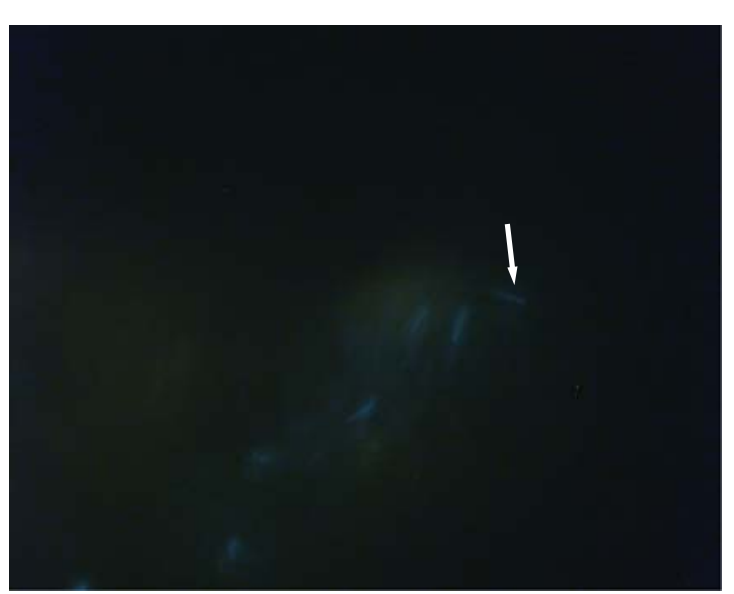

$\mathbf{E}$

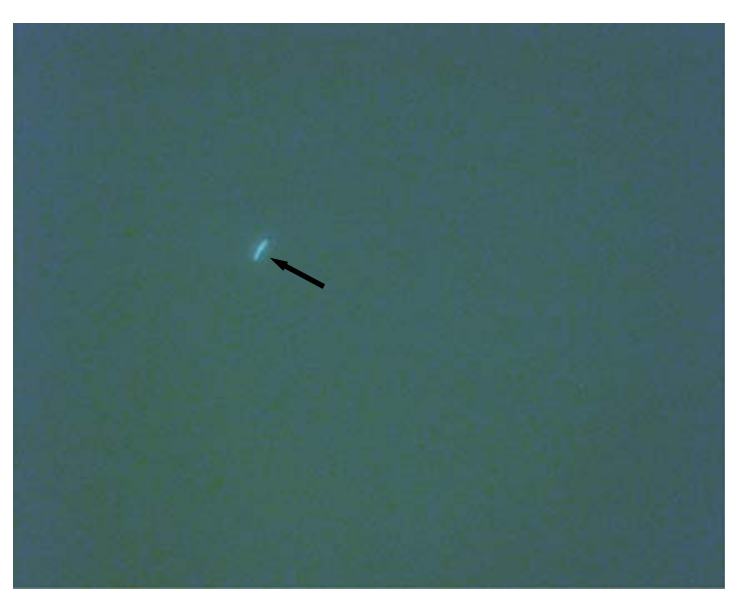

B

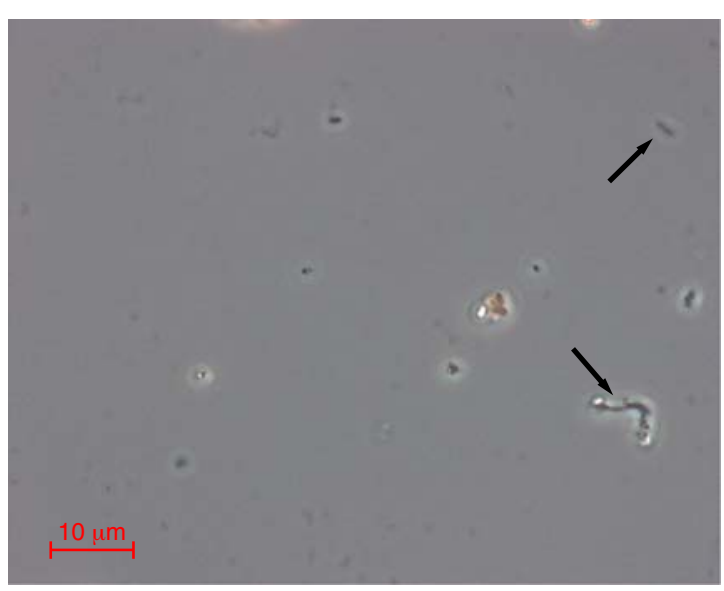

D

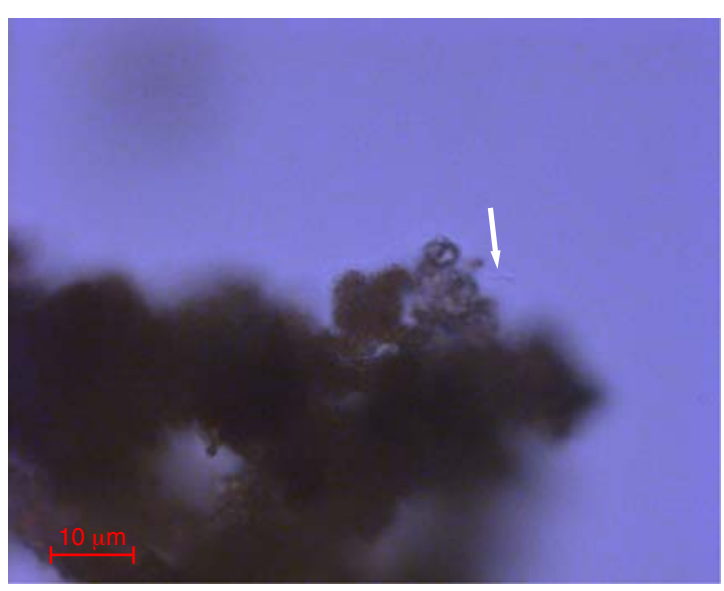

$\mathbf{F}$

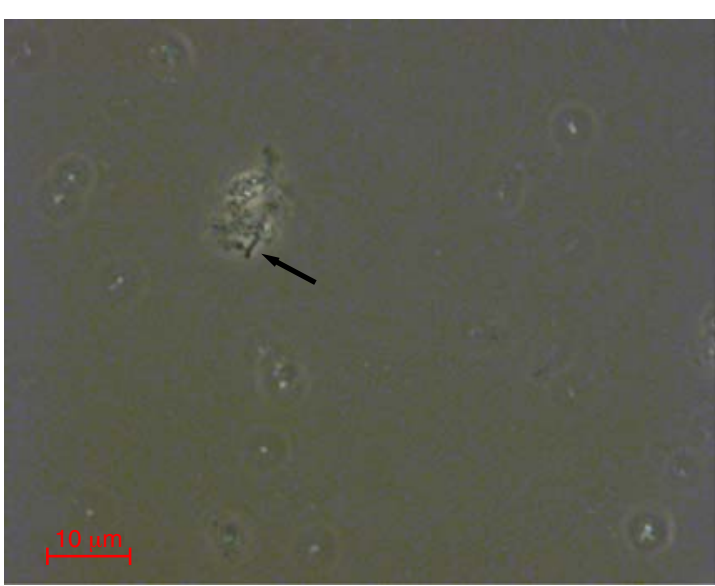


Figure F17. SEM photomicrographs with corresponding energy dispersive spectrometry spectra and quantitative analysis. cps = counts per second. A. Sample 331-C0015C-1H-3, ASW media A. B. Sample 331-C0015C$1 \mathrm{H}-3$, ASW media B. The red circle indicates the location where the energy dispersive spectrometry spectrum was taken.
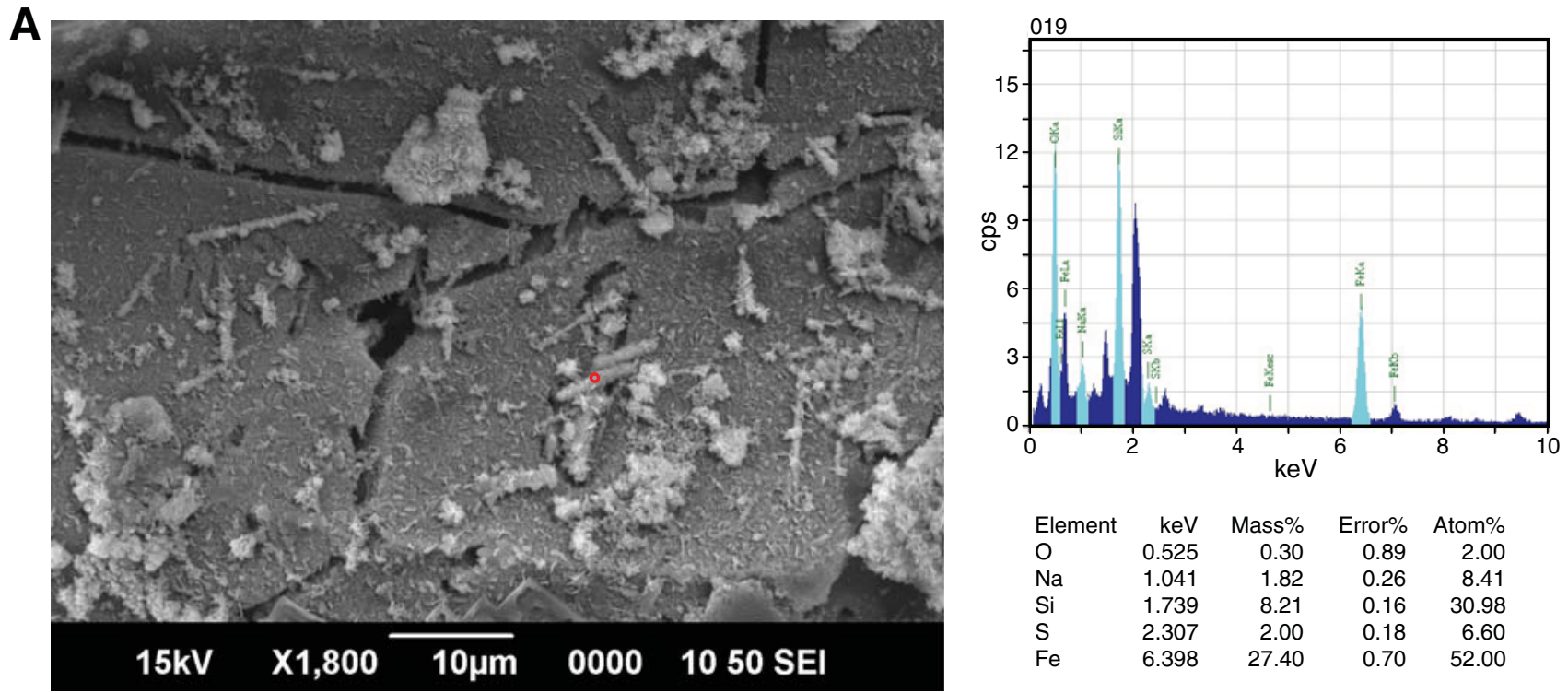

$\begin{array}{lrrrr}\text { Element } & \mathrm{keV} & \text { Mass\% } & \text { Error\% } & \text { Atom\% } \\ \mathrm{O} & 0.525 & 0.30 & 0.89 & 2.00 \\ \mathrm{Na} & 1.041 & 1.82 & 0.26 & 8.41 \\ \mathrm{Si} & 1.739 & 8.21 & 0.16 & 30.98 \\ \mathrm{~S} & 2.307 & 2.00 & 0.18 & 6.60 \\ \mathrm{Fe} & 6.398 & 27.40 & 0.70 & 52.00\end{array}$
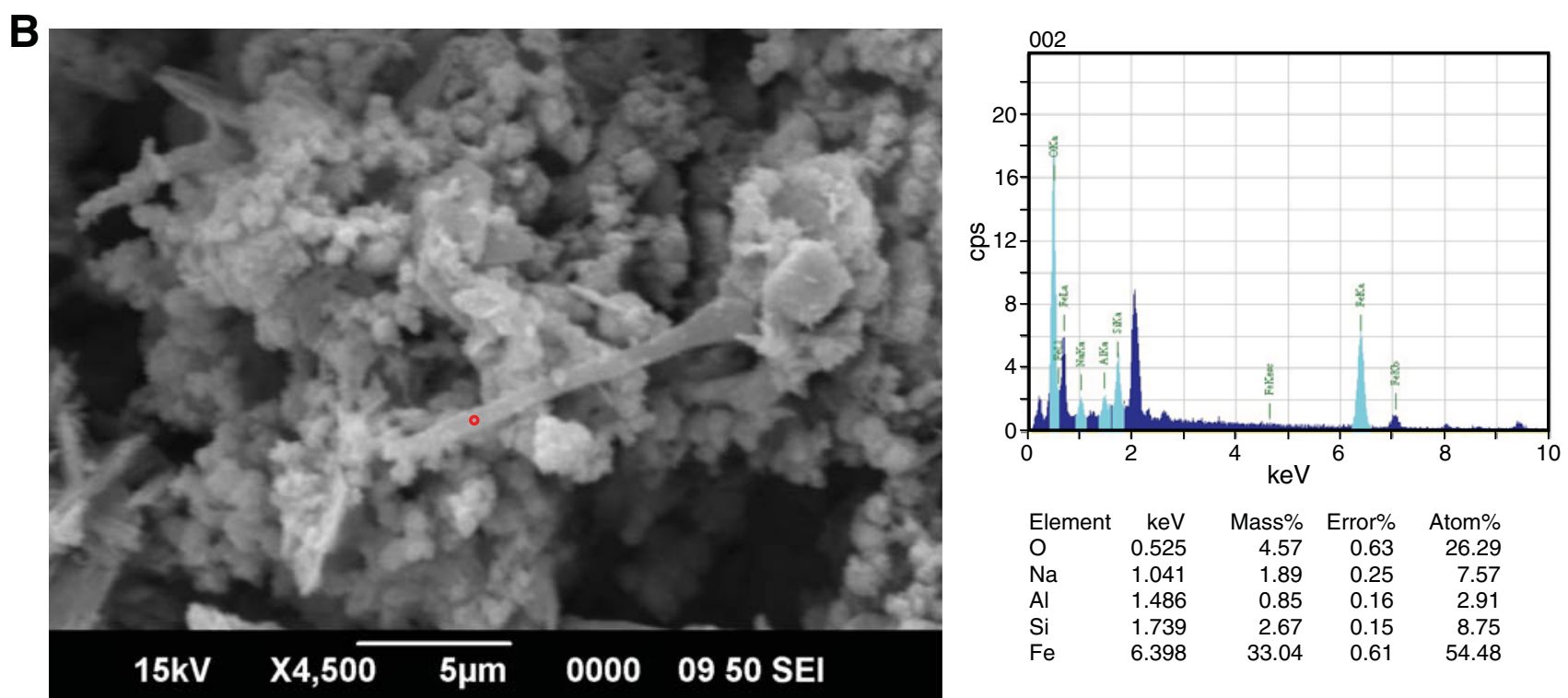
Figure F18. Phase contrast photomicrographs of Section 331-C0015C-1H-3, ASW media B, with putative bifurcated iron oxide twisted stalks indicated by arrows.
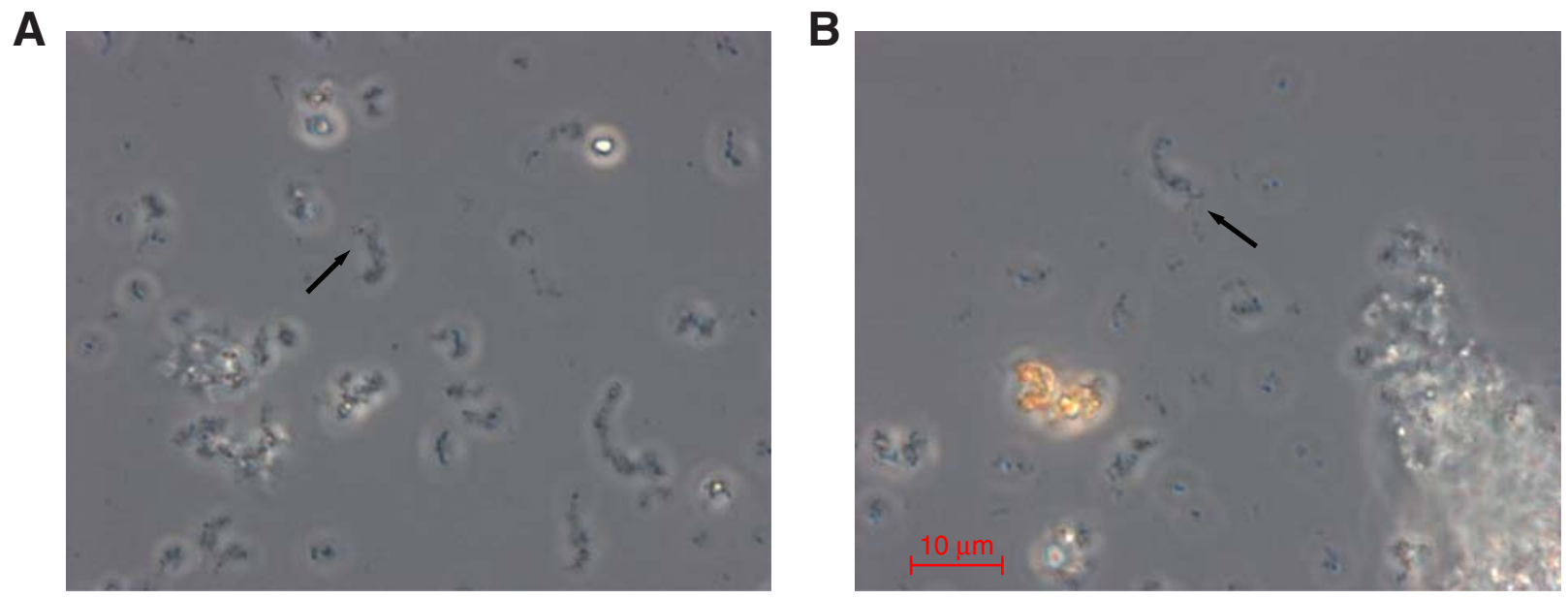
Figure F19. Plot of discrete measurements of bulk density, dry density, and grain density, Site C0015. GRA-derived bulk density from the multisensor core logger for whole-round samples (MSCL-W) is plotted as small open circles on the bulk density plot.

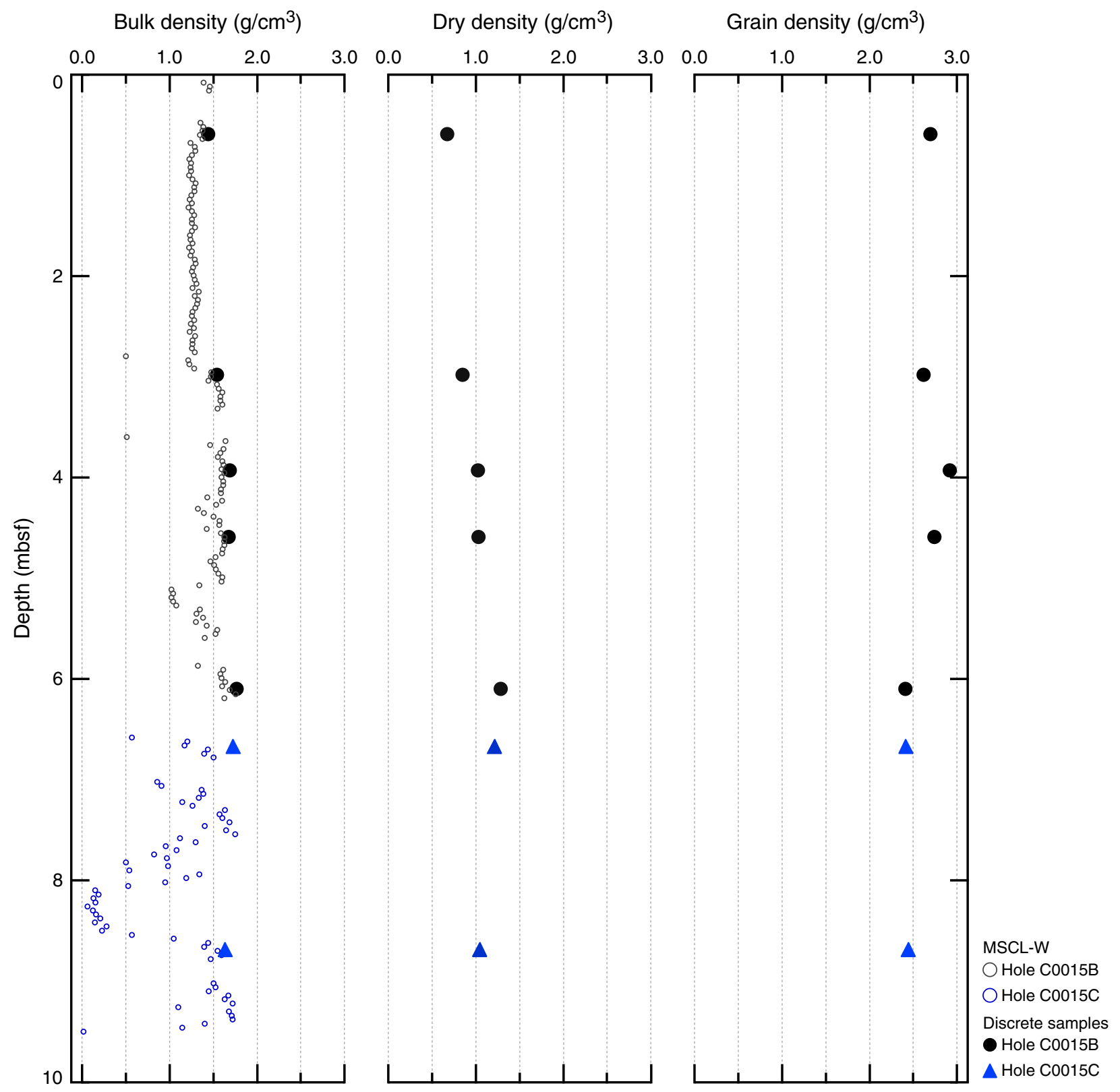


Figure F20. Plot of porosity calculated from discrete MAD measurements, Site C0015.

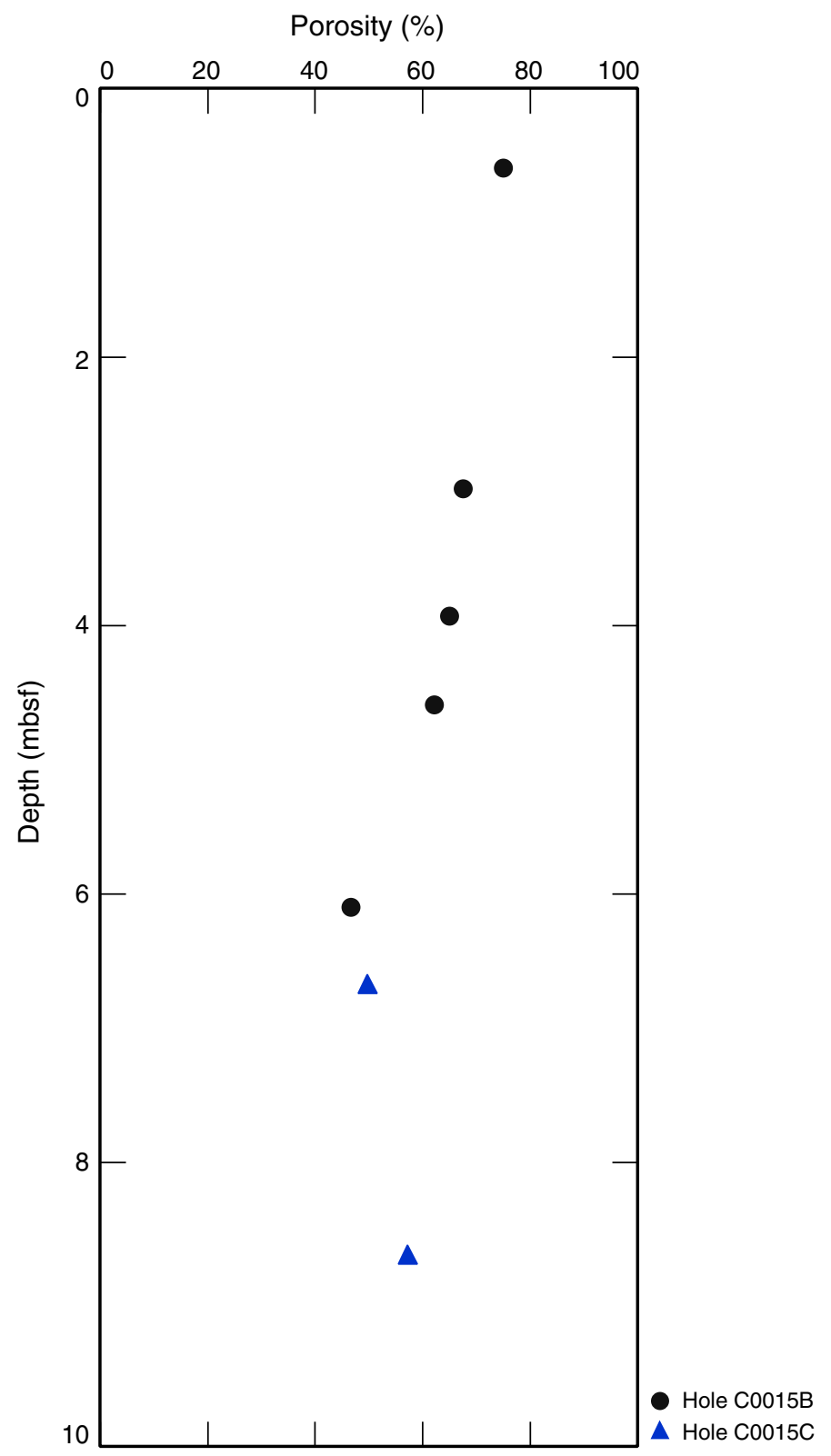


Figure F21. Plot of formation factors calculated from discrete electrical resistivity measurements, Site C0015.

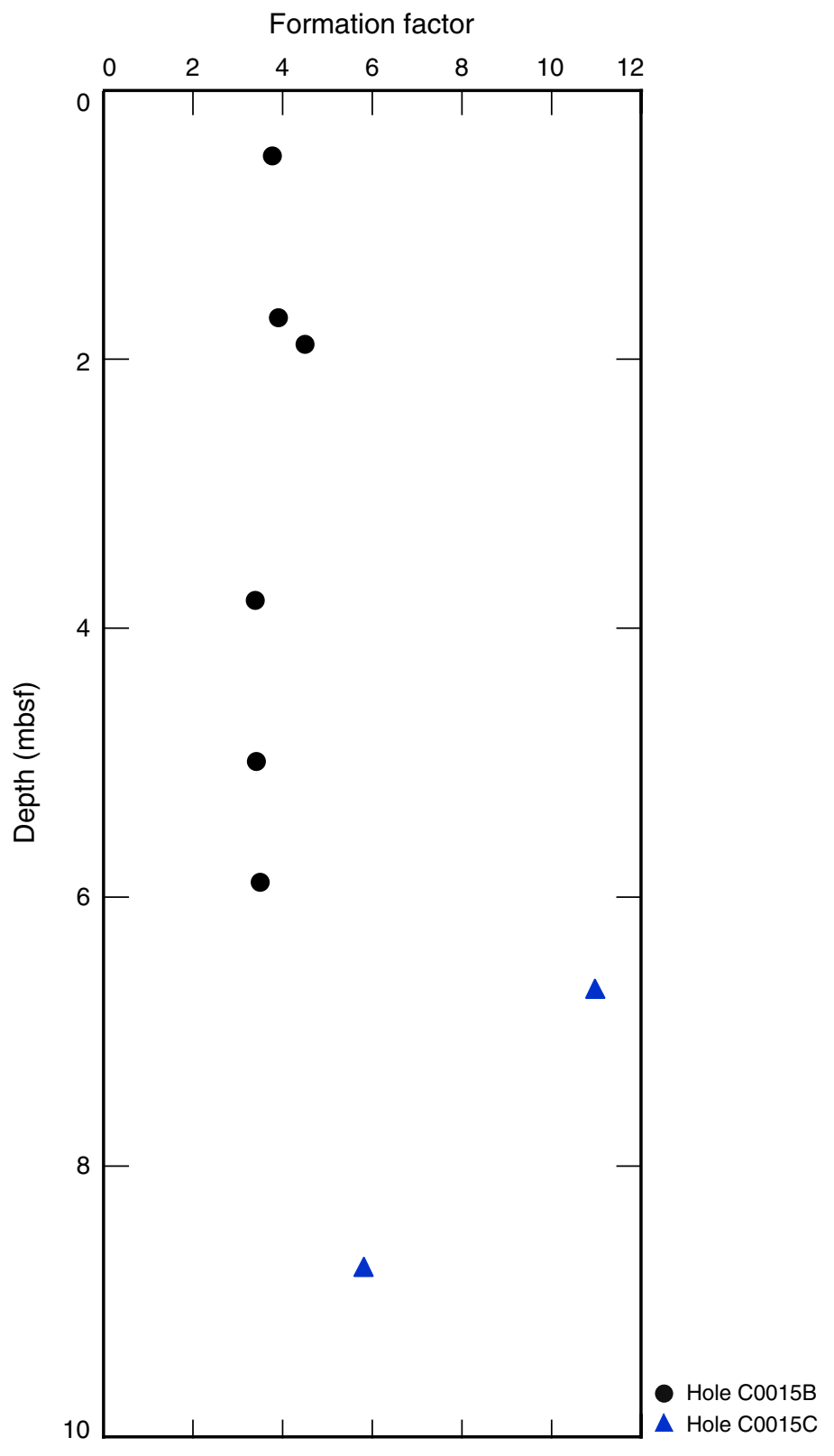


Figure F22. Plot of thermal conductivity, Site C0015.

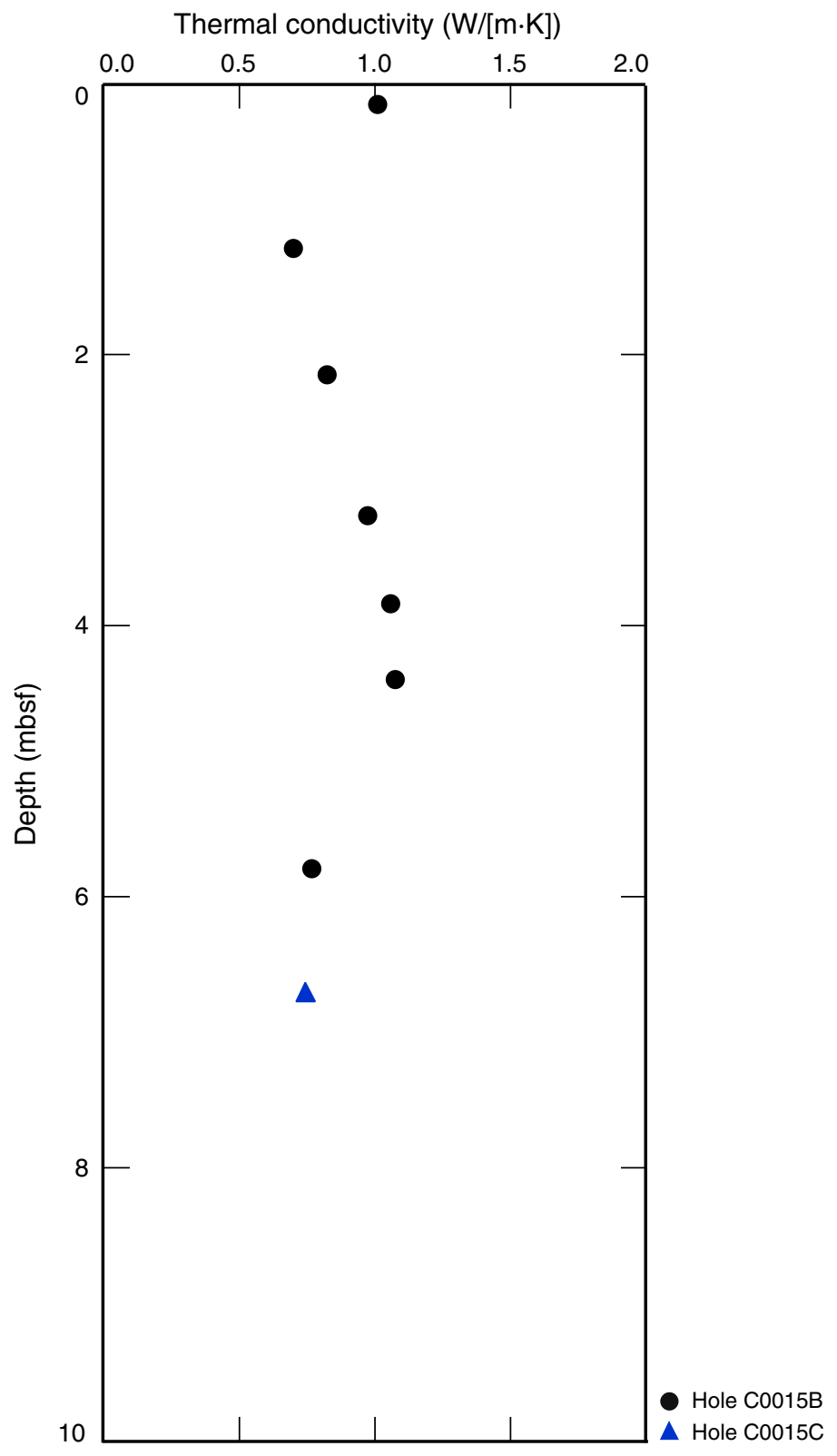


Figure F23. Plot of MSCL-W derived electrical resistivity, Site C0015.

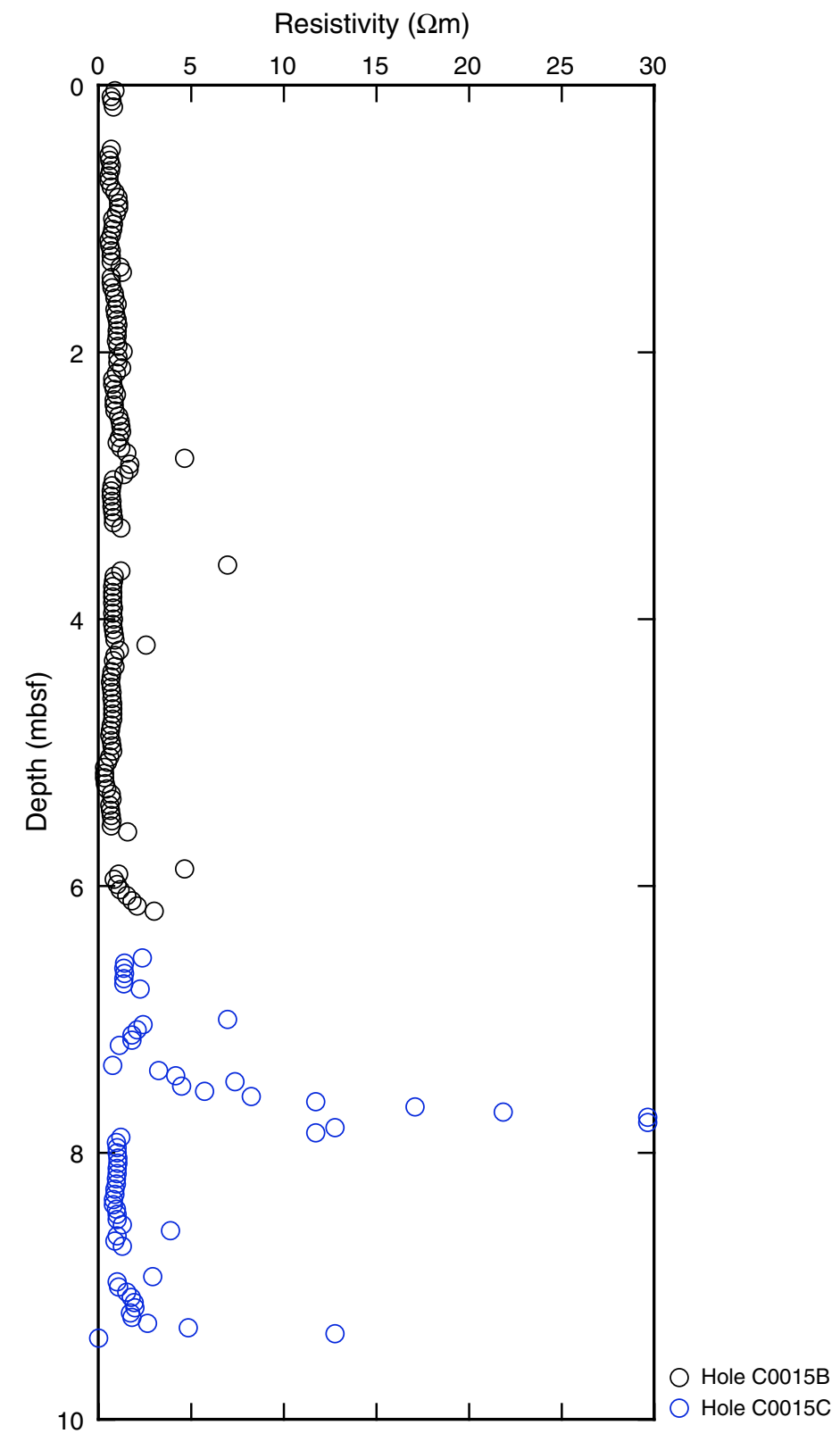


Table T1. Coring summary, Site C0015.

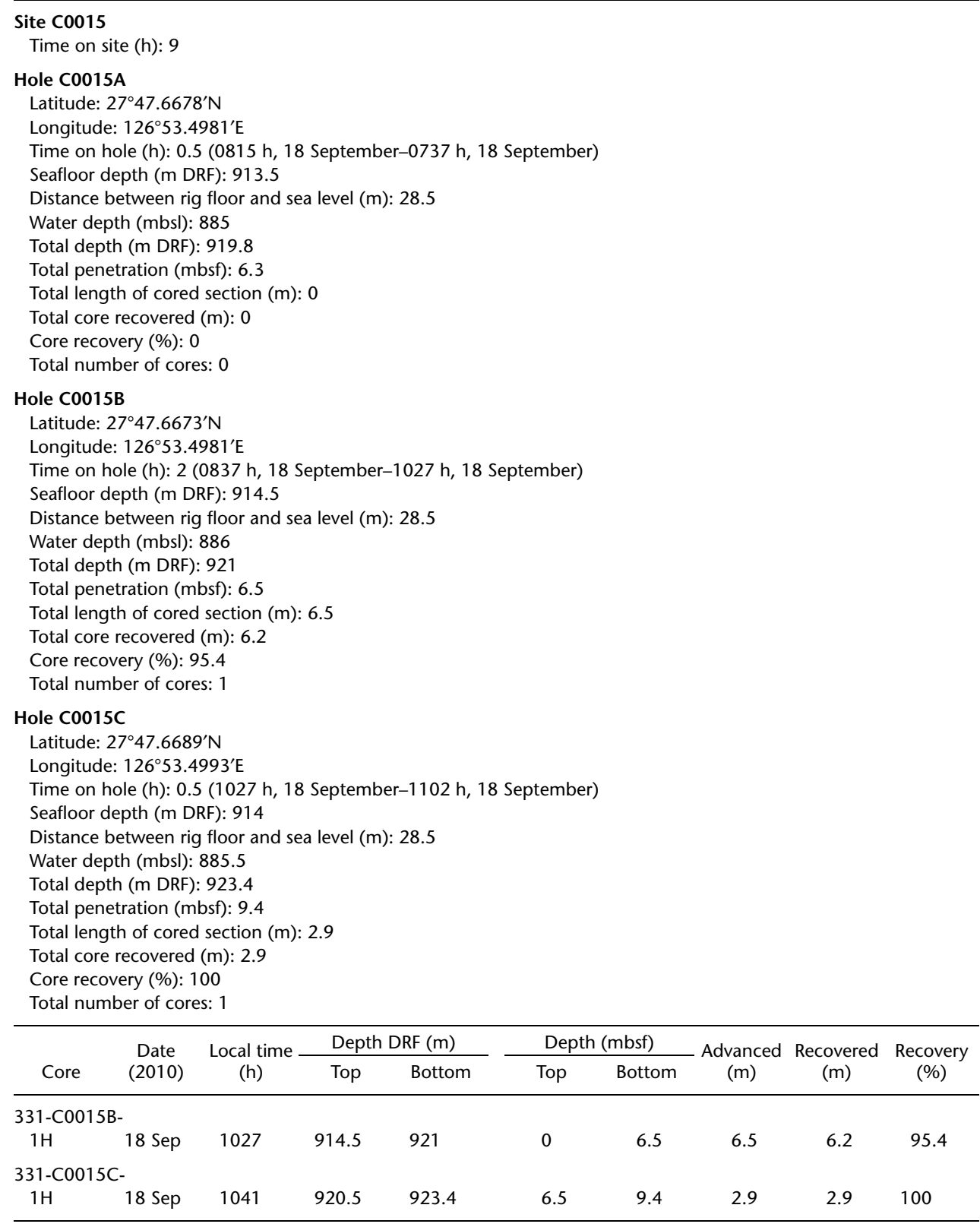

DRF $=$ drilling depth below rig floor. $\mathrm{H}=$ HPCS . 
Table T2. Lithological subunits, Site C0015.

\begin{tabular}{|c|c|c|c|c|c|}
\hline \multirow{2}{*}{$\begin{array}{l}\text { Lithological } \\
\text { subunit }\end{array}$} & \multirow[b]{2}{*}{ Description } & \multirow[b]{2}{*}{ Core } & \multicolumn{2}{|c|}{ Depth (mbsf) } & \multirow{2}{*}{$\begin{array}{l}\text { Thickness } \\
\text { (m) }\end{array}$} \\
\hline & & & Top & Bottom & \\
\hline & & \multicolumn{4}{|c|}{ 331-C0015B- } \\
\hline la & Clast-supported coarse-grained angular woody pumice gravel & $1 \mathrm{H}$ & 0 & 0.15 & 0.15 \\
\hline lb & Inverse to normally graded clast-supported coarse-grained angular woody pumice gravel & $1 \mathrm{H}$ & 0.15 & 2.95 & 2.8 \\
\hline Ic & Unconsolidated medium-grained, well-sorted foraminiferal sand & $1 \mathrm{H}$ & 2.95 & 3.05 & 0.1 \\
\hline Id & Silty foraminiferal sand & $1 \mathrm{H}$ & 3.05 & 3.2 & 0.15 \\
\hline le & Matrix-supported bioclastic gravel with $20 \%$ coral fragment and rare clasts of woody pumice in a poorly sorted mud to coarse quartz sand matrix & $1 \mathrm{H}$ & 3.2 & 5.07 & 1.87 \\
\hline If & Subrounded woody pumice gravel & $1 \mathrm{H}$ & 5.07 & 5.5 & 0.43 \\
\hline $\lg$ & Mud with pumiceous silt laminae & $1 \mathrm{H}$ & 5.5 & 5.89 & 0.39 \\
\hline Ih & Clast-supported coarse-grained angular woody pumice gravel & $1 \mathrm{H}$ & 5.89 & 5.97 & 0.08 \\
\hline \multirow[t]{2}{*}{ li } & Pumiceous grit grading to gravel at base & $1 \mathrm{H}$ & 5.97 & 6.4 & 0.43 \\
\hline & \multicolumn{5}{|c|}{ 331-C0015C- } \\
\hline lj & Unconsolidated medium-grained, well-sorted, well-rounded quartz sand & $1 \mathrm{H}$ & 6.5 & 7.35 & 0.85 \\
\hline $\mathrm{lk}$ & Clast-supported coarse-grained angular woody pumice gravel & $1 \mathrm{H}$ & 7.35 & 7.9 & 0.55 \\
\hline II & Unconsolidated medium-grained, well-sorted, well-rounded quartz sand—highly disrupted by drilling & $1 \mathrm{H}$ & 7.9 & 9 & 1.1 \\
\hline Im & Well-sorted quartz-pumice grit & $1 \mathrm{H}$ & 9 & 9.08 & 0.08 \\
\hline In & Clast-supported coarse-grained angular pumice gravel & $1 \mathrm{H}$ & 9.08 & 9.5 & 0.42 \\
\hline
\end{tabular}


Table T3. Dry mass and light microscopic observations of micropaleontology samples, Site C0015.

\begin{tabular}{|c|c|c|c|c|c|}
\hline \multirow[b]{2}{*}{ Hole, core, section, interval $(\mathrm{cm})$} & \multirow{2}{*}{$\begin{array}{l}\text { Depth } \\
\text { (mbsf) }\end{array}$} & \multicolumn{3}{|c|}{ Mass (g) } & \multirow[b]{2}{*}{ Comments } \\
\hline & & $>1 \mathrm{~mm}$ & $150 \mu \mathrm{m}$ to $1 \mathrm{~mm}$ & $63-150 \mu \mathrm{m}$ & \\
\hline \multicolumn{6}{|l|}{$331-$} \\
\hline C0015A-1H & & & & & No core \\
\hline C0015B-1H-3, 22-24 & 3.01 & & & & Microfossils present \\
\hline C0015B-1H-CC, 17.5-18.5 & 6.395 & 15.32 & 9.14 & 2.32 & Pumice clasts and fragments \\
\hline C0015C-1H-3, 25-35 & 8.905 & & & & Fe oxides \\
\hline C0015C-1H-3, 84-85 (bottom) & 9.495 & 19.14 & 1.13 & 0.54 & Pumice clasts and fragments, $\mathrm{Fe}$ oxides \\
\hline
\end{tabular}

Table T4. Foraminifers: micropaleontological observations, Site C0015.

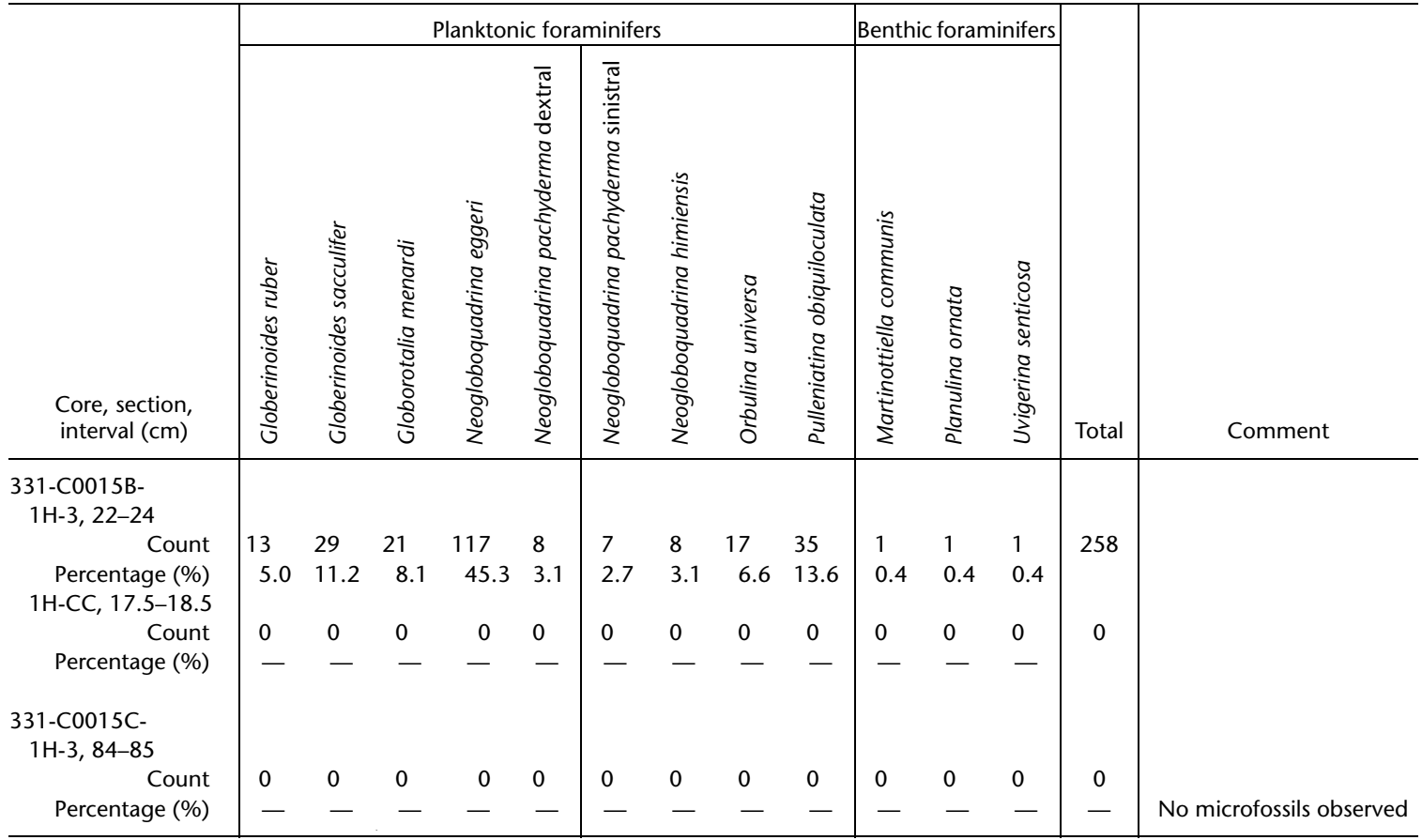

Table T5. Interpreted results of X-ray diffraction (XRD) analyses of samples, Site C0015.

\begin{tabular}{|c|c|c|c|c|}
\hline $\begin{array}{l}\text { Sample } \\
\text { number }\end{array}$ & $\begin{array}{l}\text { Core, section, } \\
\text { interval }(\mathrm{cm})\end{array}$ & Lithology & Subsampled for & Result \\
\hline & 331-C0015B- & & & \\
\hline 31482 & $1 \mathrm{H}-1,15-17$ & Oxidized brown mud with pumice & Routine chemistry & Calcite, quartz, anorthite, muscovite (minor) \\
\hline 31484 & $1 \mathrm{H}-2,70-72$ & Oxidized slightly muddy pumiceous gravel & Routine chemistry & Poorly crystalline pattern with quartz and halite \\
\hline 31486 & $1 \mathrm{H}-3,84-86$ & Anoxic calcareous gravel & Routine chemistry & Quartz, aragonite, calcite, $\mathrm{Mg}$ chlorite, muscovite \\
\hline \multirow[t]{2}{*}{31488} & $1 \mathrm{H}-5,40-42$ & Pumiceous gravel & Routine chemistry & Pyrite, quartz, muscovite/illite/montmorillonite, anorthite \\
\hline & $331-C 0015 C-$ & & & \\
\hline 31491 & $1 \mathrm{H}-1,22-24$ & Sand & Routine chemistry & Quartz, pyrite, muscovite/illite/montmorillonite \\
\hline 31493 & $1 \mathrm{H}-3,61-63$ & Oxidized pumiceous gravel & Routine chemistry & Albite, calcite, cristobalite? \\
\hline
\end{tabular}

Phases listed in approximate order of decreasing abundance. 
Table T6. Composition of interstitial pore water, Site C0015.

\begin{tabular}{|c|c|c|c|c|c|c|c|c|c|c|c|c|c|c|c|}
\hline $\begin{array}{l}\text { Core, section, } \\
\text { Interval }(\mathrm{cm})\end{array}$ & $\begin{array}{l}\text { Depth } \\
\text { (mbsf) }\end{array}$ & $\begin{array}{l}\text { Volume } \\
(\mathrm{mL})\end{array}$ & $\begin{array}{l}\text { Refractive } \\
\text { index }\end{array}$ & $\mathrm{pH}$ & $\begin{array}{l}\text { Alkalinity } \\
(\mathrm{mM})\end{array}$ & $\begin{array}{c}\mathrm{Cl} \\
(\mathrm{mM})\end{array}$ & $\begin{array}{c}\text { Phosphate } \\
(\mu \mathrm{M})\end{array}$ & $\begin{array}{c}\mathrm{NH}_{4} \\
(\mathrm{mM})\end{array}$ & $\begin{array}{c}\mathrm{Si} \\
(\mathrm{mM})^{*}\end{array}$ & $\begin{array}{c}\mathrm{Br} \\
(\mathrm{mM})\end{array}$ & $\begin{array}{c}\mathrm{SO}_{4} \\
(\mathrm{mM})\end{array}$ & $\begin{array}{c}\mathrm{Na} \\
(\mathrm{mM})\end{array}$ & $\mathrm{Na}_{\text {charge }}$ & $\begin{array}{l}\text { Difference } \\
(\%)\end{array}$ & $\mathrm{Na} / \mathrm{Cl}$ \\
\hline \multicolumn{16}{|l|}{ 331-C0015B- } \\
\hline $1 \mathrm{H}-1,20-30$ & 0.25 & 56 & 1.33934 & 7.37 & 2.418 & 539 & 2.5 & 0.03 & 0.42 & 0.871 & 29.0 & 468.6 & 463.5 & 1.09 & 0.869 \\
\hline $1 \mathrm{H}-3,55-65$ & 3.39 & 56 & 1.33935 & 7.55 & 2.842 & 548 & 2.2 & 0.029 & 0.52 & 0.874 & 29.1 & 474.3 & 472.4 & 0.41 & 0.866 \\
\hline $1 \mathrm{H}-5,15-25$ & 5.81 & 54 & 1.33934 & 7.46 & 2.326 & 549 & 4.2 & 0.025 & 0.53 & 0.882 & 29.3 & 473.7 & 474.1 & 0.09 & 0.864 \\
\hline \multicolumn{16}{|l|}{ 331-C0015C- } \\
\hline $1 \mathrm{H}-1,30-40$ & 6.84 & 31 & 1.33883 & 8.03 & 2.701 & 503 & 3.0 & 0.06 & 0.26 & 0.802 & 26.7 & 430.7 & 433.4 & 0.63 & 0.857 \\
\hline $1 \mathrm{H}-3,15-25$ & 8.81 & 40.5 & 1.33926 & 7.74 & 2.444 & 541 & 1.5 & 0.02 & 0.33 & 0.883 & 29.0 & 469.7 & 464.4 & 1.14 & 0.868 \\
\hline Bottom water ${ }^{\ddagger}$ & & & & & 2.04 & 543 & & & & 0.836 & 28.08 & 466 & & & 0.859 \\
\hline
\end{tabular}

\begin{tabular}{|c|c|c|c|c|c|c|c|c|c|c|c|c|c|c|c|c|}
\hline $\begin{array}{l}\text { Core, section, } \\
\text { Interval }(\mathrm{cm})\end{array}$ & $\begin{array}{l}\text { Depth } \\
\text { (mbsf) }\end{array}$ & $\begin{array}{c}\mathrm{K} \\
(\mathrm{mM})\end{array}$ & $\begin{array}{c}\mathrm{Mg} \\
(\mathrm{mM})\end{array}$ & $\begin{array}{c}\mathrm{Ca} \\
(\mathrm{mM})\end{array}$ & $\begin{array}{l}\mathrm{Zn} \\
(\mu \mathrm{M})\end{array}$ & $\begin{array}{l}\mathrm{Rb} \\
(\mu \mathrm{M})\end{array}$ & $\begin{array}{l}\text { Mo } \\
(\mathrm{nM})\end{array}$ & $\begin{array}{c}\mathrm{Cs} \\
(\mathrm{nM})\end{array}$ & $\underset{(n M)}{U}$ & $\begin{array}{l}\text { Boron } \\
(\mu \mathrm{M})\end{array}$ & $\begin{array}{c}\mathrm{Ba} \\
(\mu \mathrm{M})\end{array}$ & $\begin{array}{c}\mathrm{Fe} \\
(\mu \mathrm{M})\end{array}$ & $\begin{array}{c}\mathrm{Li} \\
(\mu \mathrm{M})\end{array}$ & $\begin{array}{l}\mathrm{Mn} \\
(\mu \mathrm{M})\end{array}$ & $\begin{array}{c}\mathrm{Si} \\
(\mu \mathrm{M})^{\dagger}\end{array}$ & $\begin{array}{c}\mathrm{Sr} \\
(\mu \mathrm{M})\end{array}$ \\
\hline \multicolumn{17}{|l|}{ 331-C0015B- } \\
\hline $1 \mathrm{H}-3,55-65$ & 3.39 & 11.7 & 51.6 & 10.6 & 0.298 & 1.57 & 199 & 7.4 & 13.6 & 494 & 0.36 & 0.6 & 39.2 & 1.0 & DNU & 89.1 \\
\hline $1 \mathrm{H}-5,15-25$ & 5.81 & 11.6 & 51.4 & 10.4 & 0.518 & 1.66 & 142 & 5.8 & 12.3 & 455 & 0.35 & 0.5 & 40.2 & 0.4 & DNU & 88.3 \\
\hline \multicolumn{17}{|l|}{ 331-C0015C- } \\
\hline $1 \mathrm{H}-3,15-25$ & 8.81 & 10.8 & 52.7 & 10.6 & 0.128 & 1.55 & 241 & 16.6 & 8.2 & 403 & 0.35 & 0.6 & 40.9 & 1.0 & DNU & 83.8 \\
\hline Bottom water & & 10.15 & 52.5 & 10.23 & & & & & & 410 & & & 26.2 & & & 90.6 \\
\hline
\end{tabular}

* = value was determined colorimetrically aboard ship, $\dagger=$ value was determined postcruise via ICP-OES. Volumes are crude approximates only. $\mathrm{Na}_{\text {charge }}$ is the $\mathrm{Na}$ value that we calculate from charge balance based on $\mathrm{Cl}, \mathrm{Br}$, sulfate, alkalinity, $\mathrm{Mg}, \mathrm{K}$, and Ca balance. DNU = silicon data for ICP-OES not used because of disagreement with colorimetric analyses as described in Expedition 331 Scientists (2011b). Bottom water values were calculated based on the chlorinity of samples from the uppermost $\sim 1 \mathrm{mbsf}$ from Sites C0014, C0015, and C0017 ( $n=4)$ and assuming that the elements are in constant proportion to chloride; we also make the assumption that chlorinity and chloride are the same.

Table T7. Concentrations of hydrocarbons observed in safety gas vials, Site C0015.

\begin{tabular}{lcccccccc}
\hline $\begin{array}{c}\text { Core, section, } \\
\text { interval }(\mathrm{cm})\end{array}$ & $\begin{array}{c}\text { Depth } \\
(\mathrm{mbsf})\end{array}$ & $\begin{array}{c}\mathrm{CH}_{4} \text { in } \\
\text { headspace } \\
(\mathrm{ppm})\end{array}$ & $\begin{array}{c}\mathrm{C}_{2} \mathrm{H}_{6} \text { in } \\
\text { headspace } \\
(\mathrm{ppm})\end{array}$ & $\begin{array}{c}\mathrm{C}_{3} \mathrm{H}_{8} \text { in } \\
\text { headspace } \\
(\mathrm{ppm})\end{array}$ & $\begin{array}{c}\text { Butane, ethylene, } \\
\text { and/or propylene } \\
(\mathrm{Y} \text { or } \mathrm{N})\end{array}$ & $\begin{array}{c}\text { Sediment } \\
\text { mass } \\
(\mathrm{g})\end{array}$ & $\begin{array}{c}\mathrm{CH}_{4} \text { in } \\
\text { pore water } \\
(\mu \mathrm{M})\end{array}$ & $\begin{array}{c}\mathrm{C}_{2} \mathrm{H}_{6} \text { in } \\
\text { pore water } \\
(\mu \mathrm{M})\end{array}$ \\
\hline $\begin{array}{c}331-\mathrm{C} 0015 \mathrm{~B}- \\
\begin{array}{l}1 \mathrm{H}-1,134 \\
31-\mathrm{C} 0015 \mathrm{C}-\end{array}\end{array}$ & 1.34 & 2.1 & BD & BD & $\mathrm{N}$ & 1.821 & 1.6 & $\mathrm{BD}$ \\
\begin{tabular}{l}
$1 \mathrm{H}-1,0$ \\
\hline
\end{tabular} & 6.50 & 1.6 & BD & BD & $\mathrm{Y}$ & 8.423 & 0.4 & $\mathrm{BD}$ \\
\hline
\end{tabular}

$\mathrm{BD}=$ below detection.

Table T8. Concentrations of $\mathrm{H}_{2}$ and $\mathrm{CH}_{4}$ in science gas, Site $\mathrm{C} 0015$.

\begin{tabular}{ccccccc}
\hline $\begin{array}{c}\text { Core, section, } \\
\text { interval }(\mathrm{cm})\end{array}$ & $\begin{array}{c}\text { Depth } \\
(\mathrm{mbsf})\end{array}$ & $\begin{array}{c}\mathrm{H}_{2} \text { in } \\
\text { headspace } \\
(\mathrm{ppm})\end{array}$ & $\begin{array}{c}\mathrm{CH}_{4} \text { in } \\
\text { headspace } \\
(\mathrm{ppm})\end{array}$ & $\begin{array}{c}\text { Sample } \\
\text { mass } \\
(\mathrm{g})\end{array}$ & $\begin{array}{c}\mathrm{H}_{2} \text { in } \\
\text { pore water } \\
(\mathrm{nM})\end{array}$ & $\begin{array}{c}\mathrm{CH}_{4} \text { in } \\
\text { pore water } \\
(\mu \mathrm{M})\end{array}$ \\
\hline $331-\mathrm{C} 0015 \mathrm{~B}-$ & & & & & & \\
$1 \mathrm{H}-1,134-138$ & 1.34 & $\mathrm{BD}$ & $\mathrm{BD}$ & 1.98 & 64 & $\mathrm{BD}$ \\
$1 \mathrm{H}-2,137-141$ & 2.75 & 1.8 & $\mathrm{BD}$ & 2.64 & 538 & $\mathrm{BD}$ \\
$1 \mathrm{H}-3,137-141$ & 4.16 & $\mathrm{BD}$ & 1.8 & 5.04 & $\mathrm{BD}$ & 0.3 \\
$1 \mathrm{H}-4,137-141$ & 5.57 & 1.8 & 2.6 & 8.41 & 109 & 0.2 \\
$1 \mathrm{H}-\mathrm{CC}, 0-4$ & 6.22 & $\mathrm{BD}$ & $\mathrm{BD}$ & 3.62 & $\mathrm{BD}$ & $\mathrm{BD}$ \\
$331-\mathrm{C} 0015 \mathrm{C}-$ & & & & & & \\
$1 \mathrm{H}-1,0-4$ & 6.50 & 2.4 & 380.6 & 6.83 & 463.2 & 73.8 \\
\hline
\end{tabular}

$\mathrm{BD}=$ below detection . 
Table T9. Carbon, nitrogen, and sulfur, Site C0015.

\begin{tabular}{|c|c|c|c|c|c|c|c|c|c|}
\hline $\begin{array}{l}\text { Core, section, } \\
\text { interval }(\mathrm{cm})\end{array}$ & $\begin{array}{l}\text { Depth } \\
\text { (mbsf) }\end{array}$ & $\begin{array}{c}\text { IC } \\
\text { (wt\%) }\end{array}$ & $\begin{array}{l}\mathrm{CaCO}_{3} \\
(\mathrm{wt} \%)\end{array}$ & $\begin{array}{c}\mathrm{TN} \\
(\mathrm{wt} \%)\end{array}$ & $\begin{array}{c}\mathrm{TC} \\
\text { (wt\%) }\end{array}$ & $\begin{array}{c}\text { TS } \\
\text { (wt\%) }\end{array}$ & $\begin{array}{c}\text { TOC } \\
\text { (wt\%) }\end{array}$ & TOC/TN & $\mathrm{TOC} / \mathrm{TS}$ \\
\hline \multicolumn{10}{|l|}{ 331-C0015B- } \\
\hline $1 \mathrm{H}-1,15-17$ & 0.15 & 2.572 & 21.435 & 0.034 & 2.810 & 0.041 & 0.237 & 6.984 & 5.750 \\
\hline $1 \mathrm{H}-2,70-72$ & 2.08 & 0.010 & 0.080 & 0.000 & 0.022 & 0.067 & 0.013 & NA & 0.194 \\
\hline $1 \mathrm{H}-3,84-86$ & 3.63 & 4.647 & 38.723 & 0.040 & 4.976 & 0.481 & 0.329 & 8.204 & 0.685 \\
\hline $1 \mathrm{H}-5,40-42$ & 6.01 & 0.082 & 0.681 & 0.000 & 0.095 & 0.037 & 0.014 & NA & 0.367 \\
\hline \multicolumn{10}{|l|}{ 331-C0015C- } \\
\hline $1 \mathrm{H}-1,22-24$ & 6.72 & 0.155 & 1.292 & 0.000 & 0.175 & 0.035 & 0.020 & NA & 0.562 \\
\hline $1 \mathrm{H}-3,61-63$ & 9.27 & 0.008 & 0.069 & 0.000 & 0.023 & 0.016 & 0.015 & NA & 0.922 \\
\hline
\end{tabular}

$\mathrm{IC}=$ inorganic carbon, $\mathrm{TN}=$ total nitrogen, $\mathrm{TC}=$ total carbon, $\mathrm{TS}=$ total sulfur, $\mathrm{TOC}=$ total organic carbon. $\mathrm{NA}=$ not applicable.

Table T10. Results of direct cell counting, Site C0015.

\begin{tabular}{|c|c|c|}
\hline Core, section & $\begin{array}{l}\text { Depth } \\
\text { (mbsf) }\end{array}$ & $\begin{array}{l}\text { Cells } / \mathrm{mL} \\
\text { sediment }\end{array}$ \\
\hline \multicolumn{3}{|l|}{ 331-C0015B- } \\
\hline $1 \mathrm{H}-1$ & 0.3 & $1.20 \mathrm{E}+07$ \\
\hline $1 \mathrm{H}-3$ & 3.44 & $1.06 \mathrm{E}+06$ \\
\hline $1 \mathrm{H}-5$ & 5.61 & ND \\
\hline \multicolumn{3}{|l|}{ 331-C0015C- } \\
\hline $1 \mathrm{H}-1$ & 6.885 & $8.82 \mathrm{E}+06$ \\
\hline $1 \mathrm{H}-3$ & 8.817 & $4.79 \mathrm{E}+06$ \\
\hline
\end{tabular}

ND $=$ not detected (below detection limit).

Table T11. Results of contamination tests using fluorescent microspheres, Site C0015.

\begin{tabular}{lccc}
\hline & \multirow{2}{*}{$\begin{array}{c}\text { Depth } \\
\text { Core, section }\end{array}$} & \multicolumn{2}{c}{ Spheres $/ \mathrm{mL}$ sediment } \\
\cline { 3 - 4 } & mbsf $)$ & Interior & Outer edge \\
\hline $331-$ C0015B- & & & \\
$1 \mathrm{H}-1$ & 0.3 & $\mathrm{ND}$ & $\mathrm{ND}$ \\
$1 \mathrm{H}-3$ & 3.44 & $\mathrm{ND}$ & $4.4 \mathrm{E}+02$ \\
$1 \mathrm{H}-5$ & 5.61 & $\mathrm{ND}$ & $1.8 \mathrm{E}+02$ \\
$331-\mathrm{C} 0015 \mathrm{C}-$ & & & \\
$1 \mathrm{H}-1$ & 6.885 & $4.4 \mathrm{E}+04$ & $1.5 \mathrm{E}+04$ \\
$1 \mathrm{H}-3$ & 8.817 & ND & $1.5 \mathrm{E}+02$ \\
\hline
\end{tabular}

$\mathrm{ND}=$ not detected

Table T12. Results of contamination tests using perfluorocarbon tracer (PFC), Site C0015.

\begin{tabular}{|c|c|c|c|c|c|c|c|}
\hline \multirow[b]{2}{*}{ Core, section } & \multirow{2}{*}{$\begin{array}{l}\text { Depth } \\
\text { (mbsf) }\end{array}$} & \multicolumn{2}{|c|}{$\begin{array}{l}\text { PFC concentration } \\
\text { in test vial gas phase } \\
(\mathrm{ppm})\end{array}$} & \multicolumn{2}{|c|}{$\begin{array}{l}\text { Sample weight } \\
\text { in test vial } \\
\text { (g) }\end{array}$} & \multicolumn{2}{|c|}{$\begin{array}{l}\text { PFC concentration } \\
\text { per g sample } \\
\text { (ppm) }\end{array}$} \\
\hline & & Interior & Outer edge & Interior & Outer edge & Interior & Outer edge \\
\hline \multicolumn{8}{|l|}{ 331-C0015B- } \\
\hline $1 \mathrm{H}-1$ & 0.3 & ND & $2.51 \mathrm{E}-03$ & 2.9423 & 3.1881 & ND & $7.88 \mathrm{E}-04$ \\
\hline $1 \mathrm{H}-3$ & 3.44 & ND & $1.03 \mathrm{E}-02$ & 1.6919 & 4.5666 & ND & $2.25 \mathrm{E}-03$ \\
\hline \multicolumn{8}{|l|}{ 331-C0015C- } \\
\hline $1 \mathrm{H}-3$ & 8.817 & $2.70 \mathrm{t}-02$ & $3.11 \mathrm{E}-02$ & 3.4622 & $3.195 /$ & $1.19 \mathrm{E}-03$ & $9.14 \mathrm{E}-03$ \\
\hline
\end{tabular}

$\mathrm{ND}=$ not detected 
Table T13. Cultivation experiment results for putative iron oxidizers, Site C0015.

\begin{tabular}{|c|c|c|c|c|c|}
\hline \multicolumn{2}{|c|}{ Depth (mbsf) } & \multirow{2}{*}{$\begin{array}{l}\text { Hole, core, section, } \\
\text { interval }(\mathrm{cm})\end{array}$} & \multirow{2}{*}{$\begin{array}{l}\text { Cultivation } \\
\text { time (days) }\end{array}$} & \multicolumn{2}{|c|}{ Growth media } \\
\hline Top & Bottom & & & ASW A & ASW B \\
\hline & & $331-$ & & & \\
\hline 0.30 & 0.45 & C0015B-1H-1, 30-45 & 6 & +++ & ND \\
\hline 3.44 & 3.59 & C0015B-1H-3, 65-80 & 6 & ++ & + \\
\hline 5.61 & 5.76 & C0015B-1H-5, 0-15 & 6 & - & ND \\
\hline 8.82 & 8.91 & $\mathrm{C} 0015 \mathrm{C}-1 \mathrm{H}-3,25-35$ & $5-6$ & ++ & +++ \\
\hline
\end{tabular}

$+++=$ good growth (lots of cells) $++=$ medium growth,$+=$ little growth (a few cells),$-=$ no growth. ND = no data

Table T14. Average porosity, bulk density, grain density, thermal conductivity, and formation factor, Site C0015.

\begin{tabular}{cccccc}
\hline Hole & $\begin{array}{c}\text { Porosity } \\
(\%)\end{array}$ & $\begin{array}{c}\text { Bulk density } \\
\left(\mathrm{g} / \mathrm{cm}^{3}\right)\end{array}$ & $\begin{array}{c}\text { Grain density } \\
\left(\mathrm{g} / \mathrm{cm}^{3}\right)\end{array}$ & $\begin{array}{c}\text { Thermal conductivity } \\
(\mathrm{W} /[\mathrm{m} \cdot \mathrm{K}])\end{array}$ & $\begin{array}{c}\text { Formation } \\
\text { factor }\end{array}$ \\
\hline $331-$ & & & & & \\
C0015B & $0.63 \pm 0.10$ & $1.62 \pm 0.13$ & $2.68 \pm 0.19$ & $0.92 \pm 0.15$ & $3.75 \pm 0.42$ \\
C0015C & $0.53 \pm 0.05$ & $1.68 \pm 0.07$ & $2.43 \pm 0.02$ & 0.74 & $8.39 \pm 3.65$ \\
Average: & $0.68 \pm 0.10$ & $1.64 \pm 0.11$ & $2.61 \pm 0.19$ & $0.89 \pm 0.15$ & $4.91 \pm 2.6$ \\
\hline
\end{tabular}

Error is the standard deviation of the average. 